\title{
機能性金属錯体の分子論的熱力学の展開§ Molecular Thermodynamics for Functional Metal-Complexes
}

\author{
大阪大学名誉教授＼cjkstart徂徠 道夫* \\ Research Center for Structural Thermodynamics, Osaka University \\ Emeritus Professor Michio SORAI* \\ Received December 17, 2012; E-mail: sorai@chem.sci.osaka-u.ac.jp
}

\begin{abstract}
Better understanding of materials should be achieved by complementarily employing experimental techniques which lead to either microscopic or macroscopic aspect. The specific characteristic of thermodynamics is the absence of any selection rule or selectivity. This makes a sharp contrast with various spectroscopies in which particular nuclide and/ or particular modes are selectively sensed. This review demonstrates calorimetric investigations of spin-spin interaction in transition-metal complexes and the phase transitions occurring in molecule-based materials in which electrons are directly involved. Important roles played by molecular thermodynamics are illustrated for the following subjects: (i) Spin-spin interactions in tri-nuclear metal-complex, (ii) ferromagnetic phase transition in molecule-based magnets, (iii) determination of structure in a low-dimensional assembled-metal complex, (iv) change of electronic state due to molecular motion in an organometallic compound, (v) phase transitions due to spin-crossover phenomena, (vi) phase transition due to intramolecular electron transfers in mixed-valence complexes, and (vii) phase transition due to thermochromic phenomena. Since a change in the electronic state is strongly coupled with a change in the lattice, the transition mechanisms always include interplays with various molecular motions in the lattice.
\end{abstract}

\section{1. はじめに}

このたび思いがけず、錯体化学会貢献賞を受賞する栄 誉にあずかった。錯体化学および関連分野の発展への 寄与」ということなので、特定の話題に限定せず、相当 昔にさかのぼつた回想を含め、機能性錯体を理解する上 で、分子論的熱力学がどのような役割を果たしているか を紹介したい。

筆者はこれまでに、電子が直接的に関与する錯体の相 転移に関する総説 ${ }^{1,2}$ や、分子磁性体の相転移に関する レビュー ${ }^{3)}$ 、『相転移の分子熱力学』と題する拙著 ${ }^{4)}$ を 出版してきた。本稿は主として、拙著の中の錯体に関す る分子熱力学の部分から抜粋したものである。

\section{1. 分子熱力学とその特徵}

科学の目的は自然の仕組みを明らかにすることであ り、物質の理解は化学の大きな研究目標である。そのた

連絡先著者名: 徂徠 道夫

連絡先 : 560-0043 大阪府豊中市待兼山町 1-1

大阪大学大学院理学研究科構造熱科学研究センター

Tel: 072-753-0922 Fax: 072-753-0922（自宅）

Corresponding Author: Michio Sorai

Address: Machikaneyama-cho 1-1, Toyonaka, Osaka 560-0043, Japan

${ }^{8}$ Contribution No. 35 from the Research Center for Structural Thermodynamics

Keywords:molecular thermodynamics, heat capacity, entropy, phase transition, spin crossover, spin-spin interaction, charge transfer, mixed valence, thermochromism, paramagnetic cluster
めに様々な分光法や構造解析などの手法が用いられ、ミ クロな傾面の解明がなされている。他方、マクロなエネ ルギーの側面を明らかにするのが熱力学的手法である。 物質の正しい理解には、ミクロとマクロの両面からの相 補的な知見が不可欠である。いかなる物質も、状態が変 化すると内部エネルギー、エンタルピー、エントロピー、 ギブズエネルギーのような熱力学量のいくつかが変化す る。そのような熱力学量の変化を調べることによって、 物質の性質と変化を解明するのが化学熱力学である。ボ ルツマンの原理 $S=k \ln W(k$ : ボルッマン定数）を手が かりにすると、マクロなエントロピー $S$ と微視的状態の 数 $W$ を結びつけることができるので、熱測定を通して ミクロな量子状態に関する知見を得ることができる。こ れが分子熱力学である。

熱力学には分光学などでみられる選択律や選択性が存 在しないので、系を構成している原子や分子のあらゆる 自由度（並進・振動・回転運動、伝導電子、スピン）が 反映されるのが、大きな特徴である。したがって熱力学 は、無機物から有機物、低分子から高分子、結晶から非 晶質、固体から液体・気体、単成分系から多成分系、低 温から高温と、すべてを対象にできる科学である。また 熱容量測定に限っていえば、低エネルギー領域において きわめて高いエネルギー分解能をもつ実験手法であり、 極低温ではその威力が十分に発揮されるのも大きな特徵 である。 
各種分光法には固有の時間スケールがあり、研究者は その時間スリットを通して現象を観察していることにな る。たとえば光化学ではピコ秒やへムト秒での現象を観

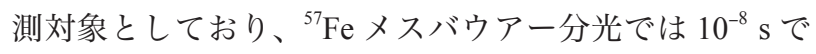
ある。これに対し、本稿で主として扱う断熱法による熱 容量測定は、数十秒から千秒の時間スケールでの観測と なる。物性測定手法の中では最も長い時間スケールに属 する。

\section{2. 熱容量とその測定法}

熱力学は様々な物理量で構成されているが、定压での 状態を議論する場合や定圧のもとで行う実験では、エン タルピー $(H)$ 、エントロピー $(S)$ 、ギブズエネルギー $(G)$ の 3 つが基本となる。定圧熱容量の定義 $C_{p} \equiv(\partial H / \partial T)_{p}$ か ら、 $C_{p}$ を温度 $T$ で積分するとエンタルピーが求められる。 定圧熱容量を温度 $T_{1}$ から $T_{2}$ まで測定し、温度に対して

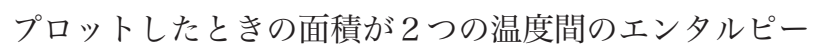
差となる。

$$
\Delta H=H\left(T_{2}\right)-H\left(T_{1}\right)=\int_{T_{1}}^{T_{2}} C_{p} \mathrm{~d} T
$$

また $\mathrm{d} H=T \mathrm{~d} S+V \mathrm{~d} p$ より $(\partial H / \partial T)_{p}=T(\partial S / \partial T)_{p}$ なので、定 圧熱容量は $C_{p} \equiv T(\partial S / \partial T)_{p}$ とも定義できる。 $C_{p} / T$ を温度 に対してプロットしたときの面積、あるいは $C_{p}$ を温度 の自然対数でプロットしたときの面積からエントロピー 差が決定される。

$$
\Delta S=S\left(T_{2}\right)-S\left(T_{1}\right)=\int_{T_{1}}^{T_{2}}\left(C_{n} / T\right) \mathrm{d} T=\int_{\ln T_{1}}^{\ln T_{2}} C_{p} \mathrm{~d} \ln T
$$

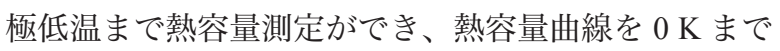
補外することができる場合は、下限温度を $T_{1}=0$ 、上限 温度を $T_{2}=T$ と書き換えて、温度 $T$ での標準モルエンタ ルピー $\left[H^{\circ}(T)-H^{\circ}(0)\right]$ と標準モルエントロピー $\left[S^{\circ}(T)-\right.$ $\left.S^{\circ}(0)\right]$ が決定される。分子の配列や配向に秩序がある完 全結晶の場合は、熱力学第三法則より $S^{\circ}(0)=0$ とおけ るので、標準ギブズエネルギー関数が次式より決定され る。

$$
\left[G^{\circ}(T)-H^{\circ}(0)\right]=\left[H^{\circ}(T)-H^{\circ}(0)\right]-T S^{\circ}(T)
$$

このように定圧熱容量を低温から測定することにより、 エンタルピーとエントロピー以外にギブズエネルギーも 決定できる。

熱力学には分光学などでみられる選択律や選択性が存 在しないので、系を構成している原子や分子のあらゆる 自由度が熱力学諸量に反映される。分子運動の自由度は 並進・回転・分子内振動であり、金属の場合には伝導電子、 磁性体では電子スピンの配向に関する寄与がある。極低 温になれば核スピンの寄与も観測される。

熱容量の代表的な決定法は、物質のエンタルピーを温
度の関数として測定する方法である。筆者らは最も正確 な熱容量值が得られる断熱法の実験装置を製作し用いて きた ${ }^{5,6)}$ 。最近は緩和法を用いた市販の実験装置が普及 しており、操作の簡便さ・試料量の少なさ・磁場印加実 験が可能などの利点から、熱容量測定を行なう研究者が 増えている。熱測定の普及の点から、好ましいことであ る。

\section{3. 物質は相転移でその本姓を露呈する}

ある温度、ある圧力で分子がどのような凝集状態をと るかは、分子の形、分子間相互作用、分子運動の 3 つの 微妙な協奏効果によって決まる。物質の安定性を決めて

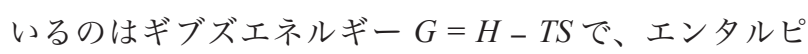
一項 $H$ とエントロピー項 $T S$ から成り立っている。分子 間相互作用が反映するのは主としてエンタルピーだが、 分子運動がより反映するのはエントロピーである。協奏 効果の微妙なバランスが崩れたときに、それまで存続し ていた相は破局を迎え、異なった相に移行する。これが 相転移である。極論すれば、「物質は相転移でその本姓 を露呈する」といえる。相転移の機構解明は興味深いテ ーマとして、昔から多くの研究者を惹きつけている。

実験的に $G 、 H 、 S$ を求める手段として熱容量測定が ある。実測の熱容量から格子振動に基づく「正常熱容量」 を差し引いたものが、相転移や熱異常に基づく「過剰熱 容量」 $\Delta C_{p}$ であり、 $T$ および $\ln T$ で積分することにより、 エンタルピーの増分 $\Delta H$ とエントロピーの増分 $\Delta S$ が 決定される。他方、ボルツマンの原理 $S=k N_{\mathrm{A}} \ln W=R \ln$ $W\left(N_{\mathrm{A}}\right.$ : アボガドロ定数、 $R$ : 気体定数) は、マクロな 熱力学量 $S$ からミクロな事象 $W$ を垣間見る重要なチャ ネルの役割を果たしている。転移エントロピー $\Delta_{\mathrm{trs}} S$ は、 高温相と低温相のエントロピーの差に対応するので $\Delta_{\mathrm{trs}} S$ $=R \ln \left(W_{\mathrm{H}} / W_{\mathrm{L}}\right)$ となる。ここで $W_{\mathrm{H}}$ と $W_{\mathrm{L}}$ は高温相と低温 相での量子状態の数である。低温相が秩序状態の場合は $W_{\mathrm{L}}=1$ なので、転移エントロピーの実測值から高温相で幾 通りの量子状態が存在するかを推定することができる。

\section{2. スピン間相互作用と熱容量}

遷移金属元素を核とする多核錯体は、常磁性クラスタ 一を芯にして、その周囲を大きな反磁性配位子がおおい かぶさったものが多い。一般にクラスター間の磁気的相 互作用は弱いので、クラスターを孤立したスピン系とみ なすことができ、スピン間相互作用を研究する上で好都 合な系である。電子スピンを半古典的なべクトルとして 扱い、多核錯体に適用したのが神戸モデルである ${ }^{7)}$ 。

多核錯体の磁気的性質が本格的に研究されたのは、 Fig. 1 に示したクロム 3 核錯体 $\left[\mathrm{Cr}_{3}^{\mathrm{III}} \mathrm{O}\left(\mathrm{O}_{2} \mathrm{CCH}_{3}\right)_{6}\left(\mathrm{H}_{2} \mathrm{O}\right)_{3}\right]$ $\mathrm{Cl} \cdot 6 \mathrm{H}_{2} \mathrm{O}$ である。オランダでこの錯体の熱容量が (2.5 - 


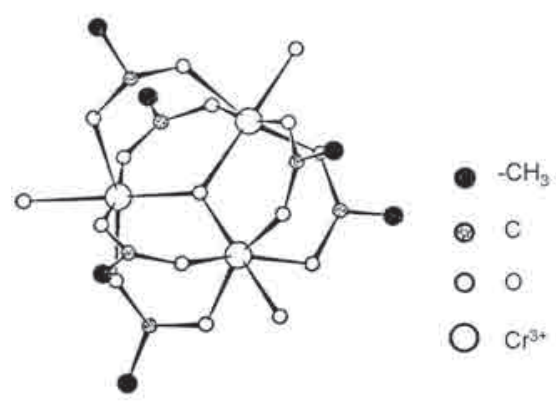

Fig. 1 Molecular structure of the trinuclear chromium cluster $\left[\mathrm{Cr}_{3} \mathrm{O}\left(\mathrm{O}_{2} \mathrm{CCH}_{3}\right)_{6}\left(\mathrm{H}_{2} \mathrm{O}\right)_{3}\right]^{+.9)}$

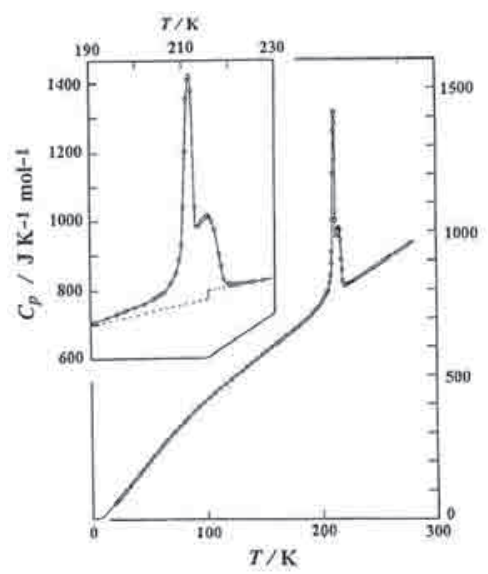

Fig. 2 Molar heat capacity of $\left[\mathrm{Cr}_{3} \mathrm{O}\left(\mathrm{O}_{2} \mathrm{CCH}_{3}\right)_{6}\left(\mathrm{H}_{2} \mathrm{O}\right)_{3}\right] \mathrm{Cl} \cdot 6 \mathrm{H}_{2} \mathrm{O}$ versus temperature. ${ }^{11)}$

6.0) K および (11 - 100) K 温度領域で測定され、なだら かな熱異常が低温で観測された ${ }^{8)}$ 。その熱容量異常は、 3 つの $\mathrm{Cr}^{3+}$ イオンで形成される正三角形クラスターの スピンエネルギー準位では説明できないので、クラスタ 一が二等辺三角形に歪んだ次式の神戸モデルによるスピ ンハミルトニアンが仮定された。

$$
H=-2 J_{0}\left(\boldsymbol{S}_{1} \cdot \boldsymbol{S}_{2}+\boldsymbol{S}_{2} \cdot \boldsymbol{S}_{3}+\boldsymbol{S}_{3} \cdot \boldsymbol{S}_{1}\right)-2 J_{1} \boldsymbol{S}_{2} \cdot \boldsymbol{S}_{3}
$$

ここで $J_{0}$ と $J_{1}$ は超交換相互作用パラメーターである。 $\boldsymbol{S}_{i}(i=1,2,3)$ はスピン演算子で、 $\mathrm{Cr}^{3+}$ の場合 $S_{1}=S_{2}=S_{3}$ $=3 / 2$ である。 $J_{0}$ が反強磁性的相互作用の場合、正三角 形クラスターで 4 重縮重であった基底準位は 2 つクラ マース 2 重項に分裂するので、低温でショットキー熱異 常が期待できる。

ところがその後、この錯体の室温での結晶構造が決定 され、クラスターの形状は正三角形であることが判明し た ${ }^{9)}$ 。正三角形のエネルギー準位では低温の熱異常を説 明できないので、正三角形を保ったまま次式のような高 次のスピン間相互作用を摂動として加えることが提案さ れた ${ }^{10)}$ 。

$$
H_{1}=-2 J^{\prime}\left[\left(\boldsymbol{S}_{1} \cdot \boldsymbol{S}_{2}\right)\left(\boldsymbol{S}_{2} \cdot \boldsymbol{S}_{3}\right)+\left(\boldsymbol{S}_{2} \cdot \boldsymbol{S}_{3}\right)\left(\boldsymbol{S}_{3} \cdot \boldsymbol{S}_{1}\right)+\left(\boldsymbol{S}_{3} \cdot \boldsymbol{S}_{1}\right)\left(\boldsymbol{S}_{1} \cdot \boldsymbol{S}_{2}\right)\right]
$$

しかし $H_{1}$ はエルミート形式ではないので、エルミー

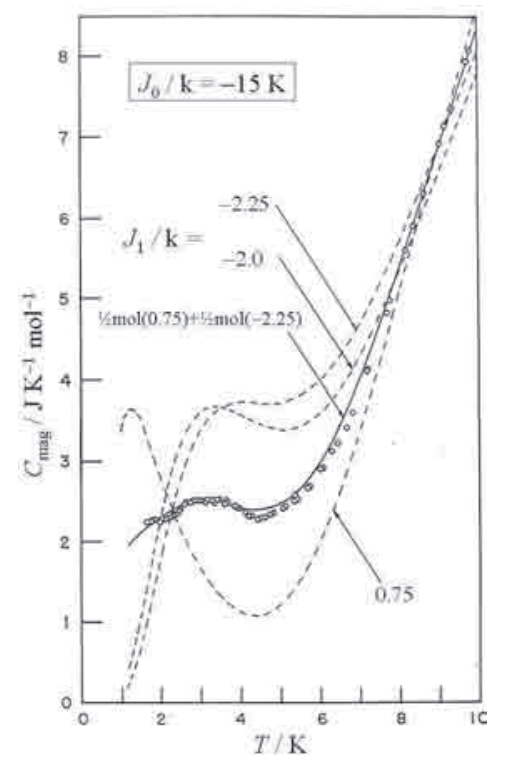

Fig. 3 Comparison of the experimental magnetic heat capacity with the theoretical values. Open circles, the experimental data; solid line, the theoretical curve calculated for $J_{0} / k=-15 \mathrm{~K}$ and $J_{1} / k=-2.25 \mathrm{~K}$ for $0.5 \mathrm{~mol}$ and $J_{0} / k=-15 \mathrm{~K}, J_{1} / \mathrm{k}=0.75 \mathrm{~K}$ for the remaining $0.5 \mathrm{~mol}$; broken curves, the theoretical curves calculated for $1 \mathrm{~mol}$ of the cluster ions with $J_{0} / k=-15 \mathrm{~K}$ and $J_{1} / k=-2.25 \mathrm{~K}$, $-2.0 \mathrm{~K}$, and $0.75 \mathrm{~K}$, respectively. ${ }^{11)}$

\section{ト形式にするには}

$$
H_{2}=-2 J^{\prime}\left[\left(\boldsymbol{S}_{3} \cdot \boldsymbol{S}_{2}\right)\left(\boldsymbol{S}_{2} \cdot \boldsymbol{S}_{1}\right)+\left(\boldsymbol{S}_{1} \cdot \boldsymbol{S}_{3}\right)\left(\boldsymbol{S}_{3} \cdot \boldsymbol{S}_{2}\right)+\left(\boldsymbol{S}_{2} \cdot \boldsymbol{S}_{1}\right)\left(\boldsymbol{S}_{1} \cdot \boldsymbol{S}_{3}\right)\right]
$$

を加えなけれげならないが、そうするとエネルギー準位 は正三角形の場合と同じになってしまうとの指摘があ り、低温での熱容量異常の解釈が再び迷宮入りとなった。

そこで筆者らが $1.5 \mathrm{~K}$ から $280 \mathrm{~K}$ の広い温度領域で熱 容量を測定したところ、低温の熱異常の他に Fig. 2 に示 したように、 $215.5 \mathrm{~K}$ に副次的なピークを伴った大きな 構造相転移が $211.4 \mathrm{~K}$ に見つかつた ${ }^{11)}$ 。この相転移は結 晶水の配向に関係したもので、配位水との水素結合を通 してクラスターに影響を及ぼすことが判明した。高温相 で正三角形であったクラスターが構造相転移で歪んだこ とになるので、二等辺三角形を仮定して解析を進めた。

実測值から格子熱容量を差し引いて得た磁気熱容量に は、 $3 \mathrm{~K}$ と $15 \mathrm{~K}$ 近辺を頂点とするなだらかな熱異常が 現れた。この常磁性クラスターは $\mathrm{Cr}^{3+}$ イオン（スピン 3/2） 3 個から構成されているので、スピンのエネルギー 準位の総数は 64 あり、それに基づくショットキー熱異 常がこれらの熱異常の原因である。10 K 以下の磁気熱 容量を示したのが Fig. 3 である。 $3 \mathrm{~K}$ 近辺を極大とする なだらかな熱異常が観測されたが、ピークの絶対值が小 さくて単純な二等辺三角形モデルでは説明がつかない。

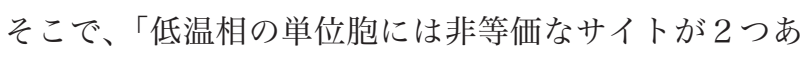
り、異なる二等辺三角形クラスターが存在する」という 仮説を立て解析を行なった。その結果、実測値との一致 

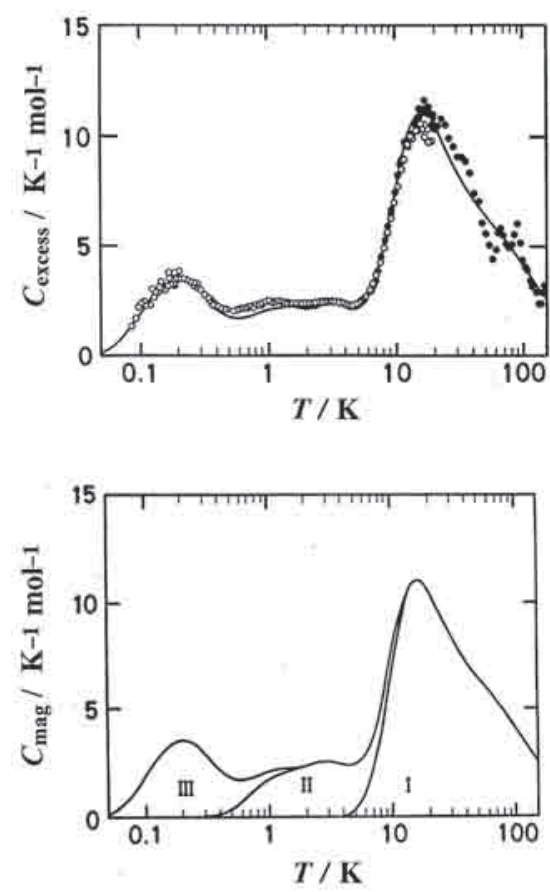

Fig. 4 Top: Excess heat capacities beyond the lattice contribution $\left(\mathrm{C}_{\text {excess }}\right)$ of $\left[\mathrm{Cr}_{3} \mathrm{O}\left(\mathrm{O}_{2} \mathrm{CCH}_{3}\right)_{6}\left(\mathrm{H}_{2} \mathrm{O}\right)_{3}\right] \mathrm{Cl} \cdot 6 \mathrm{H}_{2} \mathrm{O}$. Solid ${ }^{11)}$ and open ${ }^{17)}$ circles are the experimental values obtained from different calorimeters. Bottom: Magnetic heat capacity $\left(C_{\text {mag }}\right)$. Curve I is the theoretical magnetic heat capacity of this complex calculated for two equilateral trinuclear units $(0.5 \mathrm{~mol}$ each), while curves II and III correspond to two isosceles trinuclear units ( $0.5 \mathrm{~mol}$ each) without and with intercluster interaction, respectively. ${ }^{17)}$

が最もよかったのは、パラメーターが $\left(J_{0} / k=-15 \mathrm{~K}, J_{1} / k\right.$ $=0.75 \mathrm{~K})$ と $\left(J_{0} / k=-15 \mathrm{~K}, J_{1} / k=-2.25 \mathrm{~K}\right)$ の二等辺三角形 クラスターが $0.5 \mathrm{~mol}$ ずつ存在する場合であった ${ }^{11}$ 。こ の解釈の妥当性は、その後行なわ机た電子分光 ${ }^{12-14) 、 X}$ 線構造解析 ${ }^{15)}$ 、磁化測定 ${ }^{16)}$ なご様々な研究で証明された。

ところがもう 1 つ問題が残つた。この錯体中の不対電 子数は奇数なのでクラマース縮退が存在し、基底状態は 2 重縮重である。このままだと熱力学第三法則に反する ので、さらに低温で何らかの原因で 2 重縮重が解けるは ずである。そこで ${ }^{3} \mathrm{He} /{ }^{4} \mathrm{He}$ 希釈冷凍機を用いた極低温熱 量計を製作し、90 mKから $20 \mathrm{~K}$ の温度領域で熱容量測 定を行なった ${ }^{17)}$ 。その結果、 $0.2 \mathrm{~K}$ 近辺を中心としたな だらかなピークが新たに観測された。磁気熱容量を示し たのが Fig. 4 である。15 K 近辺を中心とする大きなピー クは正三角形クラスターのショットキー熱異常、 $3 \mathrm{~K}$ 付 近のふくらみは 2 種類の二等辺三角形に歪んだことによ るエネルギー準位の変化に対応している。 $0.2 \mathrm{~K}$ に新た に見つかったピークは基底準位が関与したものである。 しかし相転移ではないので、この熱異常は磁気的長距離 秩序に起因する基底準位のゼーマン分裂ではない。そこ で考元られるのは、奇数電子系の常磁性クラスターが弱 い相互作用を通して偶数電子系の「多量体」になる可能 性である。2 量体、4 量体、6 量体などが考元られるが、 次式で表される簡単な 2 量体（クラスター $\mathrm{a}$ と b) を仮
定して解析してみた。

$$
\begin{aligned}
H_{\text {dimer }}= & -2 J_{0 \mathrm{a}}\left(\boldsymbol{S}_{1 \mathrm{a}} \cdot \boldsymbol{S}_{2 \mathrm{a}}+\boldsymbol{S}_{2 \mathrm{a}} \cdot \boldsymbol{S}_{3 \mathrm{a}}+\boldsymbol{S}_{3 \mathrm{a}} \cdot \boldsymbol{S}_{1 \mathrm{a}}\right)-2 J_{1 \mathrm{a}} \boldsymbol{S}_{2 \mathrm{a}} \cdot \boldsymbol{S}_{3 \mathrm{a}} \\
& -2 J_{0 \mathrm{~b}}\left(\boldsymbol{S}_{4 \mathrm{~b}} \cdot \boldsymbol{S}_{5 \mathrm{~b}}+\boldsymbol{S}_{5 \mathrm{~b}} \cdot \boldsymbol{S}_{6 \mathrm{~b}}+\boldsymbol{S}_{6 \mathrm{~b}} \cdot \boldsymbol{S}_{4 \mathrm{~b}}\right)-2 J_{1 \mathrm{~b}} \boldsymbol{S}_{5 \mathrm{~b}} \cdot \boldsymbol{S}_{6 \mathrm{~b}}-2 J_{2} \boldsymbol{S}_{\mathrm{a}} \cdot \boldsymbol{S}_{\mathrm{b}}
\end{aligned}
$$

$\boldsymbol{S}_{n \mathrm{a}}(n=1,2,3)$ と $\boldsymbol{S}_{n \mathrm{~b}}(n=4,5,6)$ はそれぞれクラスター a とbに属する $\mathrm{Cr}^{3+}$ イオンのスピン演算子、 $S_{\mathrm{a}}$ と $\boldsymbol{S}_{\mathrm{b}}$ はク ラスター $\mathrm{a} と \mathrm{~b}$ の全スピン演算子、 $J_{2}$ はクラスター間の スピン間相互作用パラメーターである。結晶中に $2 つ$ の副格子が存在し、同一の副格子は同じ形の二等辺三 角形クラスターが占め、2 量体が形成されると仮定して いる。その結果、2 量体の 4 重縮重の基底準位は、1 重 と 3 重に分裂する。実測值との一致が最もよいのは、二 等辺三角形 $\left(J_{0 \mathrm{a}} / k=-16.0 \mathrm{~K}, J_{1 \mathrm{a}} / k=0.72 \mathrm{~K}\right)$ と $\left(J_{0 b} / k=-14.1\right.$ $\left.\mathrm{K}, J_{1 b} / k=-2.16 \mathrm{~K}\right)$ が、それぞれ反強磁性的相互作用 $J_{2} / k$ $=(-0.20 \mathrm{~K} \sim-0.37 \mathrm{~K})$ で 2 量体を形成する場合であった。 Fig. 4 の実線がこの理論曲線であるが、非常によい一致 をしている。これで全ての謎が解明されたことになるが、 新しい熱量計の製作もあり、解決までに 17 年間を要し たことになる。

\section{3. 最初の強磁性錯体の熱測定}

強磁性を示す分子磁性体は今日では数多く見いださ れているが、最初の例は 1960 年代中頃に報告された $\left[\mathrm{Fe}^{\mathrm{III}}(\mathrm{diEt}-\mathrm{dtc})_{2} \mathrm{Cl}\right]$ (diEt-dtc: $N, N$-diethyldithiocarbamato) で ある ${ }^{18)}$ 。Fig. 5 に同族化合物 $\left[\mathrm{Fe}^{\mathrm{III}}(\mathrm{diR}-\mathrm{dtc})_{2} \mathrm{X}\right](\mathrm{R}$ ：アル キル基、 $\mathrm{X}$ ：ハロゲン化物イオン）の分子構造を示した が、 $\mathrm{Fe}^{3+}$ は 4 つの $\mathrm{S}$ 原子と八ロゲン化物イオンによりほ ぼ四角錐状に 5 配位されており、 $\mathrm{S}$ 原子が作る基底面か ら $0.062 \mathrm{~nm}$ 離れたところに位置している。3 $3 \mathrm{~d}^{5}$ 電子配置 の $\mathrm{Fe}^{3+}$ は、 $O_{h}$ 配位子場では高スピン $\left({ }^{6} \mathrm{~A}_{1 \mathrm{~g}}: S=5 / 2\right)$ ある いは低スピン $\left({ }^{2} \mathrm{~T}_{2 \mathrm{~g}}: S=1 / 2\right)$ が基底状態となるが、 5 配位 で $C_{2 v}$ 配位子場では中間スピン状態 $\left({ }^{4} \mathrm{~A}_{2}: S=3 / 2\right)$ が安 定となる。この錯体は磁気測定および ${ }^{57} \mathrm{Fe}$ メスバウア 一分光の結果、 $T_{\mathrm{C}}=2.43 \mathrm{~K}$ 以下で強磁性体になることが 判明した ${ }^{19,20)}$ 。

筆者らはこの錯体の熱容量を $0.4 \mathrm{~K}$ から $20 \mathrm{~K}$ の温度 領域で測定し、 $T_{\mathrm{C}}=(2.412 \pm 0.008) \mathrm{K}$ に相転移を観測し

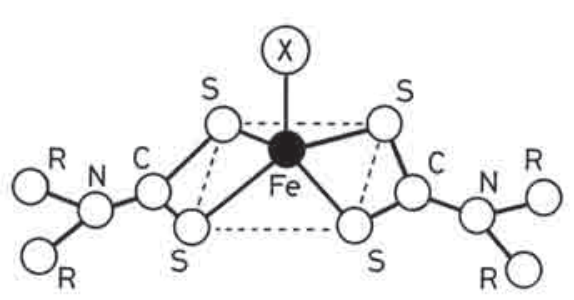

Fig. 5 Molecular structure of [Fe'"(diR-dtc) $\left.)_{2} \mathrm{X}\right](\mathrm{R}$ : alkyl-group, dtc: dithiocarbamato, $\mathrm{X}$ : halogen). ${ }^{18)}$ 


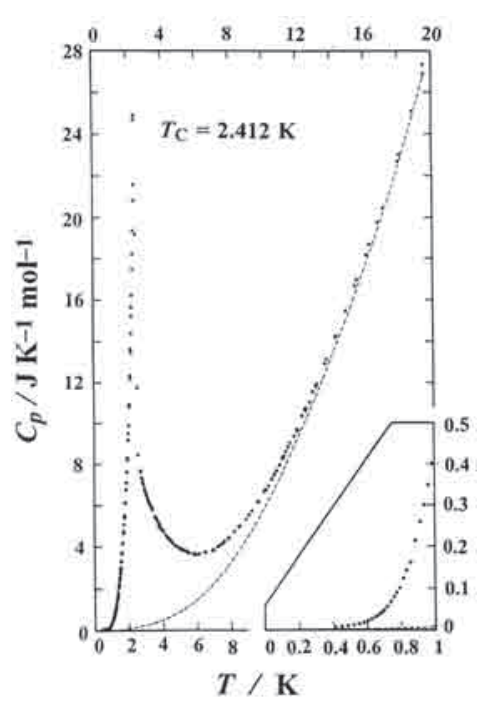

Fig. 6 Molar heat capacity of [Fe"'(diEt-dtc) ${ }_{2} \mathrm{Cl}$ ] between $0.4 \mathrm{~K}$ and $20 \mathrm{~K}$. The dashed curve represents the estimated lattice heat capacity. ${ }^{21)}$

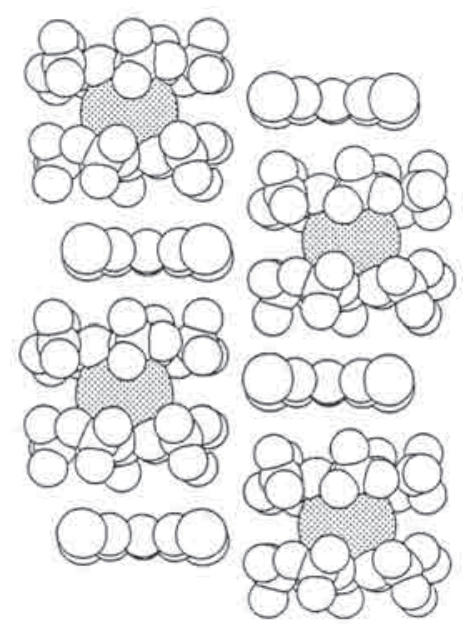

Fig. 7 Molecular packing in the crystal of $\left[\mathrm{Fe}\left(\mathrm{C}_{5} \mathrm{Me}_{5}\right)_{2}\right][\mathrm{TCNE}] \cdot{ }^{23)}$

た (Fig. 6) ${ }^{21)}$ 。図中の点線は格子熱容量である。熱異 常のエントロピー $\left(11.20 \mathrm{~J} \mathrm{~K}^{-1} \mathrm{~mol}^{-1}\right)$ がスピン多重度に基 づくエントロピー $R \ln 4\left(=11.53 \mathrm{~J} \mathrm{~K}^{-1} \mathrm{~mol}^{-1}\right)$ にきわめて 近い值なので、こ机が磁気相転移であることがわかる。 本錯体では、 $\mathrm{Fe}^{3+}$ が対称性の低い $C_{2 v}$ 配位子場に置かれ ているため、ゼ口磁場分裂をおこし、 ${ }^{4} \mathrm{~A}_{2}$ が基底 $\mid S, M_{\mathrm{S}}>$ $=\mid 3 / 2, \pm 3 / 2>$ 準位と励起 $\mid 3 / 2, \pm 1 / 2>$ 準位の 2 つのクラマ ース 2 重項に分裂している。2つの準位のエネルギー間 隔 $(\delta / k=5.5 \mathrm{~K})$ はキュリー温度 $T_{\mathrm{C}}$ より大きいので、相 転移の高温側にショットキー熱異常の形で現れる。相転 移の高温側で熱容量が大きく裾を引いているのはこのた めである。 $T_{\mathrm{C}}=2.412 \mathrm{~K}$ に現机た強磁性相転移は、磁気 的長距離秩序の形成で基底クラマース 2 重項 $\mid 3 / 2, \pm 3 / 2>$ が協同現象的にゼーマン分裂を起こしたことに起因して いる。

Miller らは電荷移動を利用して、4.8 K 以下で強磁性 体となる分子磁性体デカメチルフェロセニウム TCNE 塩 $\left[\mathrm{Fe}\left(\mathrm{C}_{5} \mathrm{Me}_{5}\right)_{2}\right]^{+}[\mathrm{TCNE}]^{-}$を創製した ${ }^{22)}$ 。Fig. 7 に示した

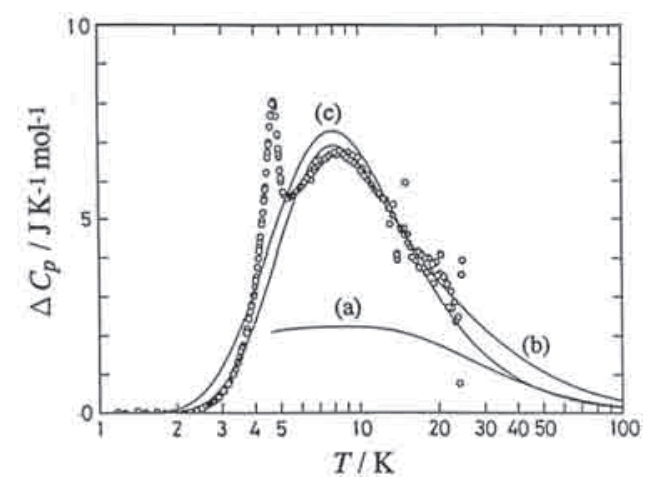

Fig. 8 Magnetic heat capacity of $\left[\mathrm{Fe}\left(\mathrm{C}_{5} \mathrm{Me}_{5}\right)_{2}\right][T C N E] .{ }^{24)}$ Curve (a): 1D Heisenberg ferromagnetic model $\left(J_{/} / k=J_{\perp} / k=13 \mathrm{~K}\right),(\mathrm{b}): 1 \mathrm{D}$ anisotropic Heisenberg ferromagnetic model $\left(J_{/} / k=25 \mathrm{~K}, J_{\perp} / J_{/ /}=\right.$ 0.5), (c): $1 \mathrm{D}$ Ising model $\left(J / / k=19 \mathrm{k}, J_{\perp} / k=0 \mathrm{~K}\right)$.

ように、結晶中では陽イオンラジカルと陰イオンラジカ ルが互いの 電子をつきあわせたような形で、交互に 積層した 1 次元カラム構造を形成し、このカラムが三角 格子状に配列している ${ }^{23)}$ 。Fig. 8 は中野と筆者による熱 容量測定から見積もつた磁気熱容量 $\Delta C_{p}$ である ${ }^{24)}$ 。横 軸の温度を自然対数でプロットしているので、曲線が囲 む面積が磁気エントロピーとなる。ちなみに実測值は $\Delta S=(12 \pm 1) \mathrm{J} \mathrm{K}^{-1} \mathrm{~mol}^{-1}$ であった。本錯体は陽イオンラジ カルと陰イオンラジカル 1 個ずつからなっているので、 スピン多重度に起因するエントロピーの期待值は $\Delta S=$ $2 R \ln 2\left(=11.53 \mathrm{~J} \mathrm{~K}^{-1} \mathrm{~mol}^{-1}\right)$ である。実測值が期待值とよ く一致している事実は、錯体が量子数 $1 / 2$ のスピンを 2 mol 有していることを示している。Fig. 8 に示したよう に、 $8.5 \mathrm{~K}$ 近傍を極大とするなだらかな熱異常と $4.74 \mathrm{~K}$ をピークとする相転移が観測されている。高温側の熱異 常は 1 次元磁気構造から予期される短距離秩序に、また 低温側の相転移は 3 次元的磁気秩序への移行に対応し、 次元クロスオーバーが起こっている。転移温度以下の工 ントロピーは $1.46 \mathrm{~J} \mathrm{~K}^{-1} \mathrm{~mol}^{-1}$ と小さく、全体の $12 \%$ に すぎない。3次元磁性体と比べると、このような擬 1 次 元物質では転移温度以上での短距離秩序がいかに大きい かがわかる。この短距離秩序の存在で、メスバウアー

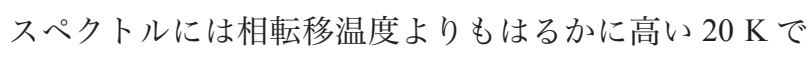
も、摇らぎによる内部磁場に基づく微細構造が現れてい る ${ }^{22)}$ 。ほぼ同時期に Chakraborty $5^{25)}$ も熱容量を測定し ており、ほぼ同様の結論を得ている。興味深いことにス ピン間相互作用は、一般の有機ラジカルで適用される 等方性ハイゼンベルクモデル $\left(J_{\perp} / J_{/ /}=1\right)$ ではなくイジン グ的である。実験結果をよく再現するのは $J_{\perp} / J_{/ /} \approx 0.5$ の 異方性ハイゼンベルクモデル（Fig. 8 の曲線 b) である。 $2 つ の$ 磁気イオン A と B の間に働く超交換相互作用の 異方性は、 $g$ 值の積 $J_{\perp} / J_{/ /} \approx g_{\perp}{ }^{\mathrm{A}} g_{\perp}{ }^{\mathrm{B}} / g_{/ /}{ }^{\mathrm{A}} g_{/ /}{ }^{\mathrm{B}}$ に比例するこ とが知られている。本錯体に扮ける $[\mathrm{TCNE}]^{-}$イオンの $g$ 值は $g_{/ /}=g_{\perp}=2.0$ であるが、 $\left[\mathrm{Fe}\left(\mathrm{C}_{5} \mathrm{Me}_{5}\right)_{2}\right]^{+}$イオンは $g_{/}$ = 4.0、 $g_{\perp}=1.3$ である ${ }^{26) 。 す な わ ち ~} J_{\perp} / J_{/ /} \approx 0.33$ となり、 


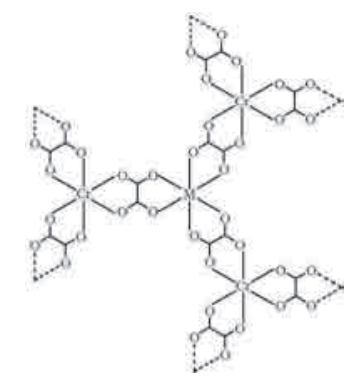

Fig.9 $\left[\mathrm{M}^{\prime \prime} \mathrm{Cr} \mathrm{rl}^{\prime \prime}(\mathrm{ox})_{3}\right]^{-}$network structure $(\mathrm{M}=\mathrm{Mn}, \mathrm{Fe}, \mathrm{Co}, \mathrm{Ni}, \mathrm{Cu}, \mathrm{Zn}$; $\mathrm{H}_{2} \mathrm{Ox}=$ oxalic acid).

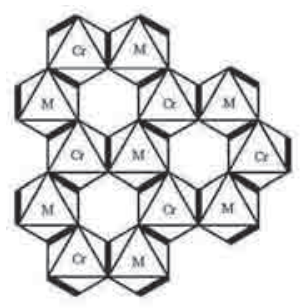

(a)

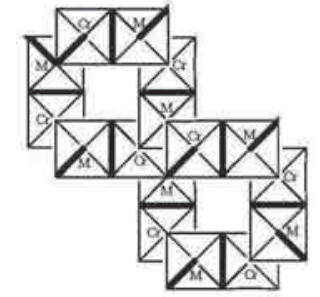

(b)
Fig. 10 Possible schematic network structure of $\left[\operatorname{MCr}(0 x)_{3}\right]^{-}$. (a) 2D honeycomb structure and (b) 3D helical structure. ${ }^{27)}$

熱測定から推定された異方性 $J_{\perp} / J_{/ /} \approx 0.5$ を支持してい る。このように、スピン間相互作用の磁気異方性の度合 いも、熱測定から解析できるのである。

\section{4. 熱容量から集積型金属錯体の構造を決定}

常磁性の低分子を 3 次元的にパッキングして強磁性体 を作る試みは、分子間相互作用が反強磁性的になること が多いので成功例は多くない。大川ら ${ }^{27)}$ は架橋配位子 を用いて一気に 2 次元や 3 次元のネットワークを構築 する戦略を立て成功した。Fig. 9 は大川らの集積型金属 錯体のネットワーク構造 $\left[\mathrm{M}^{\mathrm{II}} \mathrm{Cr}{ }^{\mathrm{III}}(\mathrm{ox})_{3}\right]_{\infty}^{-}(\mathrm{M}=\mathrm{Mn}, \mathrm{Fe}, \mathrm{Co}$, $\mathrm{Ni}, \mathrm{Cu}, \mathrm{Zn} ; \mathrm{H}_{2} \mathrm{Ox}=$ シュウ酸）で、2 種類の遷移金属イオ ンをシュウ酸イオンで架橋したものである。6配位八面 体のユニット $\left[\mathrm{M}(\mathrm{ox})_{3}\right]$ と $\left[\mathrm{Cr}(\mathrm{ox})_{3}\right]$ は $D_{3}$ 対称を有し、3 つの配位子が $D_{3}$ 軸まわりで左手らせんに配位する $\Delta$ 異 性体と右手らせんに配位する $\Lambda$ 異性体が存在する。隣 接する $\left[\mathrm{M}(\mathrm{ox})_{3}\right]$ と $\left[\mathrm{Cr}(\mathrm{ox})_{3}\right]$ が $(\Delta+\Lambda)$ の組み合わせの場 合は、Fig. 10aのような 2 次元八ニカム（蜂の巣）格子 が形成され、 $(\Delta+\Delta)$ または $(\Lambda+\Lambda)$ の場合は Fig. 10b の ような 3 次元らせん格子となる。しかし単結晶が得られ ず構造解析が進まなかつたので、いずれの構造が実現し ているか未解決であった。

Fig. 11 は $\left\{\mathrm{N}\left(n-\mathrm{C}_{4} \mathrm{H}_{9}\right)_{4}\left[\mathrm{Cu}^{\mathrm{II}} \mathrm{Cr}^{\mathrm{III}}(\mathrm{ox})_{3}\right]\right\}_{\infty}$ の磁気熱容量で ある ${ }^{28,29)}$ 。6 $6.98 \mathrm{~K}$ に相転移が観測されたが、この温度以 下で自発磁化 ${ }^{27)}$ が生じており、この相転移は強磁性か ら常磁性への転移である。転移点の高温側に大きな裾を ひいているので、スピンは 2 次元格子を形成していると

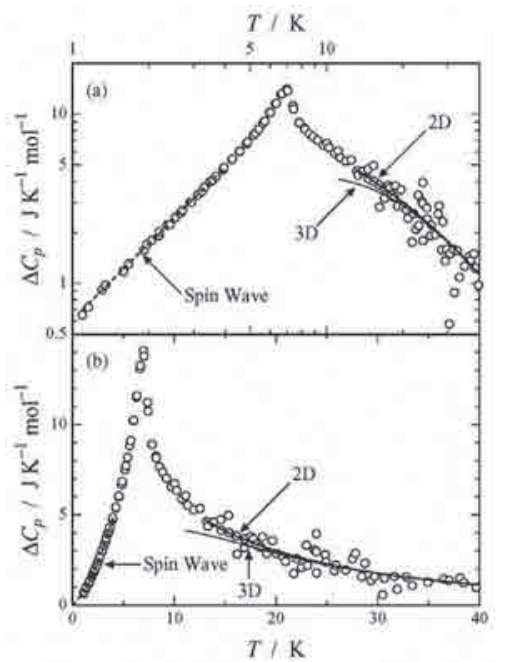

Fig.11 Excess heat capacities due to the magnetic phase transition of $\left\{\mathrm{N}\left(n-\mathrm{C}_{4} \mathrm{H}_{9}\right)_{4}\left[\mathrm{CuCr}(\mathrm{ox})_{3}\right]\right\}_{\infty}$ on (a) logarithmic scale and (b) normal scale. Thick curves represent the 2D structure, while thin curves correspond to the 3D structure. Dashed curves at the lowest temperature region indicate the spin wave contribution. ${ }^{29)}$

推論できる。転移エントロピーは $\Delta S=17.14 \mathrm{~J} \mathrm{~K}^{-1} \mathrm{~mol}^{-1}$ と決定されたが、この值は $\mathrm{Cu}^{2+}$ イオン (スピン 1/2) と $\mathrm{Cr}^{3+}$ イオン (スピン 3/2) のスピン多重度に基づくエン トロピー $R \ln (2 \times 4)=17.29 \mathrm{~J} \mathrm{~K}^{-1} \mathrm{~mol}^{-1}$ とよく一致してい る。

熱容量の形を見る限り2 次元構造を示唆しているが、 その場合のスピン配列は Fig. 10a に示したようにトポロ ジカルには 2 次元ハニカム構造なので、最隣接の常磁性 金属イオンの数はわずかに 3 である。最隣接数は 1 次元 鎖で 2、2 次元正方格子で 4、三角格子で 6、3 次元単 純立方格子で 6、面心立方格子で 12 なので、本錯体の 3 は、 2 次元あるいは 3 次元のいずれの構造を形成するに しても異常に小さいことがわかる。もしこの集積型錯体 が 3 次元構造を形成したとしても、最隣接スピン数がこ のように小さいと摇らぎの効果が顕著になり、3 次元で も相転移温度の高温側に大きな裾をひくことが予想され る。そこで橋口ら ${ }^{29)}$ は、2 次元および 3 次元ハイゼン ベルクモデルについて、短距離秩序に基づく熱異常をパ ーデ (Padé) 近似を適用した高温展開法で求め、実測の 熱容量との比較を行なった。その結果が Fig. 11 の 2 つ の曲線である。最初に相転移温度から十分離れた高温領 域で実験值にフィットさせ、スピン間相互作用の最適值 を $J / k=5.0 \mathrm{~K}$ と決定した。この領域では 2 次元と 3 次元 の区別は無いが、近似の度を高め相転移温度に近づくに つれ格子次元の差が顕著になってくる。20 K 以下では 2 次元格子の方が明らかによく一致している。すなわち、 熱容量の定量的な解析から、この集積型金属錯体の磁気 構造は 2 次元八ニカム格子であることが判明した。

ここで興味深いことは、最隣接スピン数が少ないとき には 3 次元構造でも熱容量が高温側に大きく裾をひくこ 
とである。相互作用するスピンの数が少ないほど、近距 離秩序の摇らぎが大きいことを示している。したがって、 単に空間的な次元だけで熱力学的性質を議論するのは危 険であることがわかる。

Fig. 11 の中で破線で示した低温熱容量の温度依存性 は $T^{1.51}$ であった。この指標はスピン波理論の式 $C_{\mathrm{sw}} \propto T^{d / n}$ $\left[C_{\mathrm{sw}}\right.$ : スピン波熱容量、 $d:$ 磁気格子の次元、 $n:=1$ (反 強磁性体) ; = 2 (強磁性体とフェリ磁性体) ] に照らし 合わせると $d / n=3 / 2$ で近似できる。これは 3 次元強磁 性体に対応する。すなわち本錯体では 2 次元強磁性八イ ゼンベルク相互作用が強いことが特徴であるが、2次元 層の間に存在する弱い磁気的相互作用のために次元クロ スオーバーが起こり、極低温での長距離秩序状態は 3 次 元強磁性が実現したと解釈できる。

類似化合物 $\left\{\mathrm{P}\left(\mathrm{C}_{6} \mathrm{H}_{5}\right)_{4}\left[\mathrm{Mn}^{\mathrm{II}} \mathrm{Cr}^{\mathrm{III}}(\mathrm{ox})_{3}\right]\right\}_{\infty}$ の単結晶構 造解析をDecurtins $~^{30)}$ が行ない、2 次元ハニカム 構造であることを明らかにした。構造が明らかにな つた錯体の熱容量測定 ${ }^{29)}$ を行なったところ、 $\{\mathrm{N}(n-$ $\left.\left.\mathrm{C}_{4} \mathrm{H}_{9}\right)_{4}\left[\mathrm{CuCr}(\mathrm{ox})_{3}\right]\right\}_{\infty}$ と同様の結論を得た。

磁気異方性や格子次元は熱容量に敏感に反映するの で、熱容量の解析から、このように確かな知見が得られ るのである。

\section{5. 熱測定から明らかになった有機金属化合物の 電子状態}

筆者が特に興味を惹かれようになった相転移は、電 子が直接的に関与するものであり、スピンクロスオー バー、電荷移動、サーモクロミズム現象などである。 そのきっかけとなったのは、有機金属化合物 $\left[\mathrm{Co}_{3}\left(\eta^{5}-\right.\right.$ $\left.\left.\mathrm{C}_{5} \mathrm{H}_{5}\right)_{3}\left(\mu_{3}-\mathrm{S}\right)_{2}\right]$ の電子が関与する相転移だったので、最初 にこの相転移を紹介しておきたい。

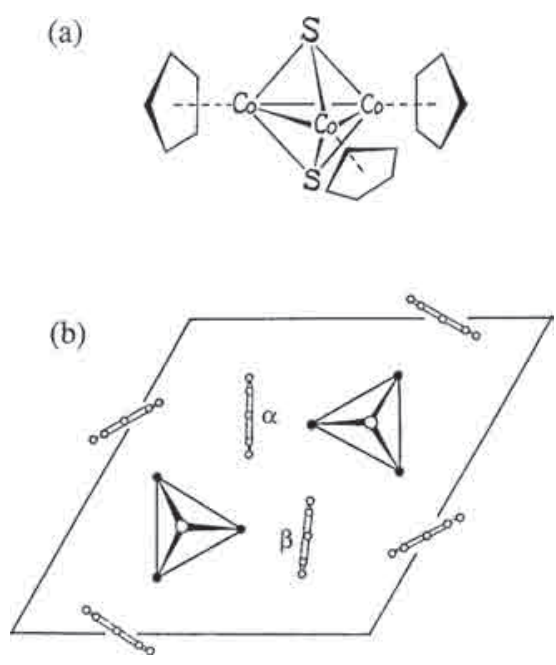

Fig. 12 (a) Molecular configuration of $\left[\mathrm{Co}_{3}\left(\mathrm{C}_{5} \mathrm{H}_{5}\right)_{3} \mathrm{~S}_{2}\right]$ and (b) projection on the (001) plane of the crystal structure at room temperature. ${ }^{37)}$
1968 年に大塚ら ${ }^{31)}$ は、新しく合成した有機金属化合 物 $\left[\mathrm{Co}_{3}\left(\mathrm{C}_{5} \mathrm{H}_{5}\right)_{3} \mathrm{~S}_{2}\right]$ の磁化率が $340 \mathrm{~K}$ から $196 \mathrm{~K}$ の温度領 域ではキュリー・ワイス則に従うが、そこから $150 \mathrm{~K} に$ かけて急激に減少し、ついには反磁性になることを見い だした。低温ではスピン $S=0$ の 1 重項であり、室温で は有効磁気モーメントが $\mu_{\mathrm{eff}}=2.50 \mu_{\mathrm{B}}$ で、 $S=1$ の 3 重項 の值 $\mu_{\mathrm{eff}}(S=1)=2.80 \mu_{\mathrm{B}}$ に近いので、この物質の磁気的 挙動は、基底 1 重項一励起 3 重項スキームに対応してい る。また室温での予備的な構造解析の結果、分子構造は Fig. 12 のようであり、類似化合物 $\left[\mathrm{Ni}_{3}\left(\mathrm{C}_{5} \mathrm{H}_{5}\right)_{3} \mathrm{~S}_{2}\right]$ の分子 構造および結晶構造 ${ }^{32)}$ と類似していることがわかった。 3つの Co 原子が正三角形に並び、その上下に S 原子が 配置して三方複錘面体を形成している。正五角形のシク ロペンタジエニル環は Co 原子が作る平面に垂直だが、 興味深いことに分子は $D_{3 h}$ という高い対称性を有してい ることである。Co 原子が作る平面が鏡映面になるため には、 5 員環は $C_{5}$ 対称軸まわりで自由回転するか、あ るいは $36^{\circ}$ 異なる 2 方向を無秩序に配向している必要が ある。

筆者ら ${ }^{33)}$ は、この 5 員環の運動と磁気的性質の相関 に興味をもって 1971 年に熱容量測定を行ない、Fig. 13 の結果を得た。192.5 K をピークとする大きな相転移が 見いだされ、その裾は $120 \mathrm{~K}$ あたりまで及んでいる。転 移エントロピーは $28.9 \mathrm{~J} \mathrm{~K}^{-1} \mathrm{~mol}^{-1}$ にも達した。この值を 説明するために、シクロペンタジエニル 5 員環の再配向 運動と分子の電子状態の協同現象的なカップリングを作 業仮説として、以下のようなメカニズムを提案した。室 温相での再配向運動はフェロセン結晶における 5 員環 の運動 ${ }^{34)}$ と同じと仮定し、1つのシクロペンタジエニ

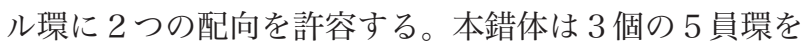
有しているが、それらの再配向運動が独立に行なわれて いると仮定する。低温相では 5 員環は再配向運動ができ

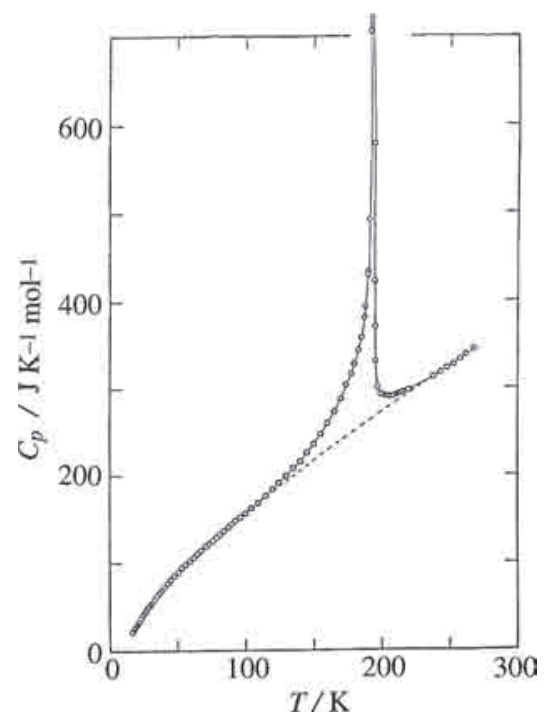

Fig. 13 Molar heat capacity of $\left[\mathrm{Co}_{3}\left(\mathrm{C}_{5} \mathrm{H}_{5}\right)_{3} \mathrm{~S}_{2}\right]$. Broken curve is the estimated normal heat capacity. ${ }^{33)}$ 
ない静止状態だとすると、相転移での分子あたりのコン フォメーション数の変化は $8\left(=2^{3}\right)$ なので、再配向に関 するエントロピーは $\Delta S$ (orientation) $=R \ln 8\left(=17.28 \mathrm{~J} \mathrm{~K}^{-1}\right.$ $\left.\mathrm{mol}^{-1}\right)$ となる。他方、磁気測定から、スピンに関しては 基底 1 重項一励起 3 重項スキームが妥当とされている。 後述するように、常磁性の高温相では 1 重項と 3 重項の エネルギー差が小さいと考えられるので、スピン多重度 としては $4(=1+3)$ とみなせるこの場合のスピンエン トロピーは $\Delta S(\operatorname{spin})=R \ln 4\left(=11.53 \mathrm{~J} \mathrm{~K}^{-1} \mathrm{~mol}^{-1}\right)$ である。 $\Delta S$ (orientation) と $\Delta S\left(\right.$ spin) の和は $28.81 \mathrm{~J} \mathrm{~K}^{-1} \mathrm{~mol}^{-1}$ であり、 実測值 $\Delta S(\mathrm{obsd})=28.9 \mathrm{~J} \mathrm{~K}^{-1} \mathrm{~mol}^{-1}$ とよく一致するので、 このモデルは妥当であろう。

つぎに問題となるのは、シクロペンタジエニル環が再 配向運動をするとなぜ電子状態が変化し、基底 1 重項と 励起 3 重項のエネルギー差が縮まるかである。ここでは Co 原子の $3 \mathrm{~d}$ 軌道が関与した 4 つの反結合分子軌道と 6 個のフロンティア電子のみを考察することにする。大 塚ら ${ }^{31)}$ によると、3つの Co 原子の軌道が結合し、 $\left(2 \phi_{1}\right.$ $\left.-\phi_{2}-\phi_{3}\right) / \sqrt{6}$ と $\left(\phi_{2}-\phi_{3}\right) / \sqrt{2}$ の 2 重縮重の反結合分子軌道 $e^{\prime *}\left(d_{x^{2}-y^{2}}\right)$ が形成される。 $\phi_{i}$ は $i$ 番目のCo 原子の軌道で ある。座標軸は、Co 原子から 5 員環の中心に向う軸を $z$ 座標、 3 つの Co 原子が形成する平面内に $x$ 座標、右手 系を完成する方向を $y$ 座標とする。同様に、 $d_{z^{2}}$ も 2 重 縮重の反結合分子軌道 $e^{* *}\left(d_{z^{2}}\right)$ を形成する。 $d_{z x}$ と $d_{x y}$ 軌 道は非縮重の反結合分子軌道 $a_{2}{ }^{\prime *}\left(d_{z x}\right)$ と $a_{1}{ }^{\prime *}\left(d_{x y}\right)$ となる。 これらの反結合分子軌道のエネルギー準位を模式的に示 したのが Fig. 14 である。低温では 6 個のフロンティア 電子のなかで 4 個が $e^{\prime *}\left(d_{x^{2}-y^{2}}\right)$ 軌道に、2 個が $a_{2}{ }^{\prime *}\left(d_{z x}\right)$ 軌 道に収容され、スピン状態は 1 重項となる。

室温で常磁性となるためには、これらの分子軌道が特 殊な温度変化をしなければならない。 $d_{x^{2}-y^{2}}$ 軌道と $d_{x y}$ 軌 道はシクロペンタジエニル 5 員環の $\pi$ 電子軌道と直交し ており、また $d_{z^{2}}$ 軌道は 5 員環の $\pi$ 電子軌道に軸対称の 形で入り込んでいるので、シクロペンタジエニル環が再 配向運動をしても、 $\pi$ 電子と $\mathrm{d}$ 電子の間の相互作用はそ
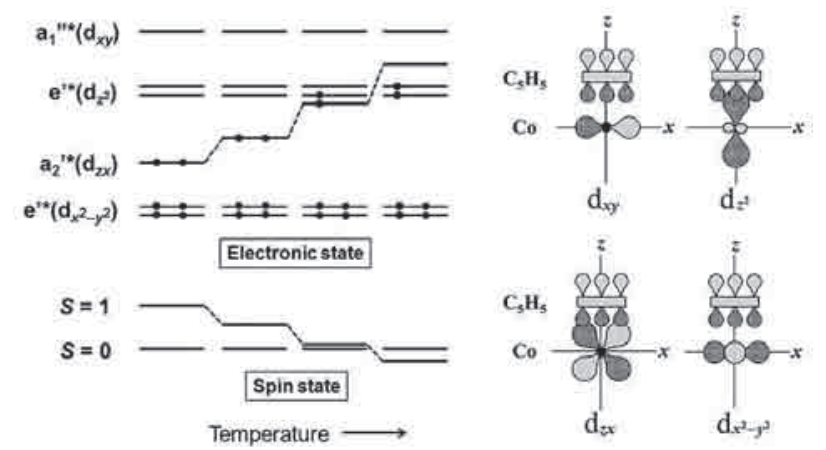

Fig. 14 Left: Temperature dependence of the electronic and spin states of $\left[\mathrm{Co}_{3}\left(\mathrm{C}_{5} \mathrm{H}_{5}\right)_{3} \mathrm{~S}_{2}\right]$ (see the text for the meaning of the molecular orbital symbols). ${ }^{33)}$ Right: Relative arrangement of the $\pi$ orbitals of $\mathrm{C}_{5} \mathrm{H}_{5}$-ring and the d-orbitals of cobalt atom.
れほど影響を受けない。したがつて、 $e^{\prime *}\left(d_{x^{2}-y^{2}}\right) 、 e^{\prime *}\left(d_{z^{2}}\right) 、$ $a_{1}{ }^{\prime *}\left(d_{x y}\right)$ の 3 つの分子軌道は、Fig. 14 に示したように温 度変化しないであろう。ところが $d_{z x}$ 軌道は $z$ 方向への 軌道の拡がりがあるので、シクロペンタジエニル環の回 転により $\pi$ 電子と $\mathrm{d}$ 電子の重なりが増えるため、電子 間反発で $a_{2}{ }^{\prime *}\left(d_{z x}\right)$ 軌道は不安定化すると考えられる。そ の結果、空軌道だった $e^{* *}\left(d_{z^{2}}\right)$ に接近し、場合によれば 準位のクロスオーバーが起こると考えられる。結果とし て、基底 1 重項一励起 3 重項スキームや基底 3 重項状態 が可能となる。室温での磁気測定では、基底 3 重項より 基底 1 重項一励起 3 重項スキームがよい近似なので、室 温での電子とスピンエネルギー準位は Fig. 14 の右端に 示したようになっているのであろう。そのため、スピン エントロピーは $R \ln 3$ ではなく $R \ln 4$ となる。筆者らの 1971 年の論文 ${ }^{33)}$ では、フロンティア電子の数を間違っ て 8 としたが、特定の反結合分子軌道の温度変化で電子 とスピンの状態を説明するこのアイデアは本質をついて いると、Dahl ら ${ }^{35)}$ は 20 年後の 1991 年の論文で評価し てくれた。Frisch と Dahl ${ }^{36)}$ は ${ }^{1} \mathrm{H}$ NMR のデー夕解析で、 $a_{2}{ }^{*}$ 分子軌道のエネルギーが温度変化することを、1972 年に確認している。

本化合物の室温での結晶構造については、1972 年に Frisch と Dahl ${ }^{36)}$ が簡単な報告をしているが、低温相と高 温相の両相での詳細な構造決定は、1979 年に上條と渡 辺 ${ }^{37)}$ により行なわれた。Fig. $12 \mathrm{~b}$ は室温での結晶構造で ある。六方晶系で空間群は $P 6_{3} / m(Z=2)$ である。分子は $\overline{6}$ の対称を有しているので、 $\mathrm{S}-\mathrm{S}$ 軸まわりに $C_{3}$ 回転軸 があり、3つの Co 原子で形成される面は鏡映面となる。 シクロペンタジエニル 5 員環が $C_{5}$ 対称軸まわりで $36^{\circ}$ 異なる 2 方向を無秩序に配向していると、この条件を満 たすことになり、配向エントロピーを算出する際に仮定 したことと符合している。低温相も六方晶系だが室温で の格子の超格子構造を形成し $Z=18$ となる。 $\mathrm{Co}_{3} \mathrm{~S}_{2}$ はも はや三方複錘面体にはならず、3つのシクロペンタジエ ニル環も非等価となり、特定の方位に静止した構造にな る。超格子構造を伴う相転移は 2 次相転移になることが 多いので、Fig. 13 の熱容量が大きな裾をひいているのは、 このためと考えられる。

熱測定から、Fig. 14 に示したような電子軌道エネル ギー準位の温度変化という珍しい現象が推察された。今 後は量子化学計算に基づいた裏づけが望まれる。

\section{6. スピンクロスオーバー現象と相転移}

\section{1. 最初のスピンクロスオーバー錯体の熱測定}

スピンクロスオーバー現象の可能性は、理論的には 1954 年の田辺と菅野の論文 ${ }^{38)}$ で指摘されていたが、実 験的な証拠が得られたのは 1967 年の König と Madeja に 


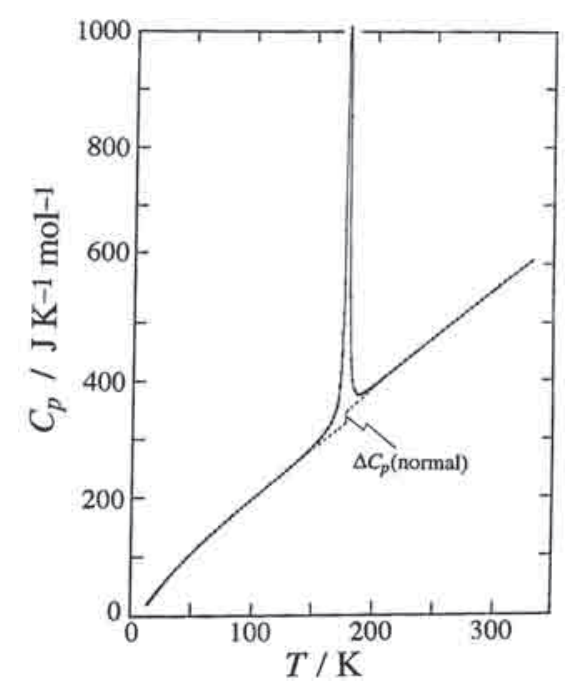

Fig. 15 Molar heat capacity of $\left[\mathrm{Fe}(\mathrm{NCS})_{2}(\text { phen })_{2}\right]$. Broken curves indicate the normal heat capacities. ${ }^{41,42)}$

よる $\left[\mathrm{Fe}^{\mathrm{II}}(\mathrm{NCX})_{2}(\mathrm{phen})_{2}\right](\mathrm{X}: \mathrm{S}$ または $\mathrm{Se} 、 \mathrm{phen}: 1,10-$ フェナントロリン) に関する論文 ${ }^{39)}$ である。この錯体 が異常な磁気的性質を示すことを Baker と Bobonich ${ }^{40)}$ が 1964 年に報告したが、 2 量体形成による異常と結論し、 スピンクロスオーバー現象であることに気づかなかった のは、さぞ悔やまれたことであろう。

スピンクロスオーバーが実在するという論文に、筆 者も扮おいに刺激され、早速これら2種類の錯体の熱 容量測定を行ない、興味深い知見を得た ${ }^{41,42}$ 。Fig. 15 は $\left[\mathrm{Fe}^{\mathrm{II}}(\mathrm{NCS})_{2}(\mathrm{phen})_{2}\right]$ のモル熱容量である。176.29 K にス ピンクロスオーバーに基づく相転移ピークが観測され、 相転移エントロピーは大きな值 $\Delta_{\mathrm{tr} S} S=(48.8 \pm 0.7) \mathrm{J} \mathrm{K}^{-1}$ $\mathrm{mol}^{-1}$ であった。電子状態は ${ }^{1} \mathrm{~A}_{1 \mathrm{~g}}$ から ${ }^{5} \mathrm{~T}_{2 \mathrm{~g}}$ に変化するので、 スピン多重度の変化に基づくエントロピーは $\Delta S(\mathrm{spin})=$ $R \ln (5 / 1)=13.38 \mathrm{~J} \mathrm{~K}^{-1} \mathrm{~mol}^{-1}$ である。また $\mathrm{A}_{\mathrm{gg}}$ 基底項から $\mathrm{T}_{2 \mathrm{~g}}$ 基底項へ変化するので、軌道角運動量の変化が相転 移エントロピーに及ぼす寄与は $\Delta S($ orbital $)=R \ln (3 / 1)=$ $9.13 \mathrm{~J} \mathrm{~K}^{-1} \mathrm{~mol}^{-1}$ になる。しかし実際の結晶では、鉄原子 が置かれている配位子場は立方対称 $O_{\mathrm{h}}$ より低いので、 軌道縮重は解けている。たとえば正方対称場 $D_{4 h}$ や 3 回 対称場 $D_{3 d}$ になると、 $O_{h}$ での基底項 ${ }^{5} \mathrm{~T}_{2 g}$ は ${ }^{5} \mathrm{~B}_{2}$ や ${ }^{5} \mathrm{~A}_{1}$ と なる ${ }^{43)}$ 。この場合には、軌道縮重はエントロピー変化に 寄与しなくスピンオンリー (spin-only) となる。

そうすると、実測の転移エントロピーの中で占めるス ピンエントロピーの割合は $27 \%$ にすぎず、残りの $73 \%$ はスピン以外に起因することになる。スピンクロスオー バー現象は $\mathrm{e}_{\mathrm{g}}$ と $\mathrm{t}_{2 \mathrm{~g}}$ 軌道の間での電子移動を伴うので、 低スピン (LS) から高スピン (HS) 状態に移行すると、金 属原子 (M) と配位子 (L) との間の距離が 10 20 pm も長 くなる。そのため主として $\mathrm{ML}_{6}$ の骨格振動やその他の 分子内振動が極端にソフト化し、振動数の変化に基づく エントロピーの増分となる。たとえば、 $\mathrm{Fe}-\mathrm{N}($ phen) の伸
縮振動は LS の $372 \mathrm{~cm}^{-1}$ から HS の $217 \mathrm{~cm}^{-1} に 155 \mathrm{~cm}^{-1}$ ソフト化し、Fe-N(NCS) では $530 \mathrm{~cm}^{-1}$ から $247 \mathrm{~cm}^{-1}$ に $283 \mathrm{~cm}^{-1}$ もシフトする ${ }^{44)}$ 。すなわち相転移エントロピー には、スピン以外の格子振動（フォノン系）からの寄与 が圧倒的に大きいことになる。相転移でフォノンの寄与 が大きく変わるため、低温相と高温相の正常熱容量にも Fig. 15 に示したように、転移温度で $\Delta C_{p}($ normal $)=18.7 \mathrm{~J}$ $\mathrm{K}^{-1} \mathrm{~mol}^{-1}$ もの段差を生じることになる。スピンクロスオ ーバーはスピン状態が劇的に変化する現象なので、スピ ンが主役を担っているように思わ机がちだが、電子とフ オノンのカップリングによる複合効果として起こるのが 現象の本質であることを、1974 年の熱容量測定の研究 42) で明らかにした。

2000 年に、Bousseksou ${ }^{45)} ら$ は $\left.\mathrm{Fe}(\mathrm{NCS})_{2}(\mathrm{phen})_{2}\right]$ 錯体 のラマン分光を $300 \mathrm{~K}$ と $100 \mathrm{~K}$ で行ない、振動数の大き なシフトを確認している。また Brehm ら ${ }^{46)}$ は密度汎関 数法で HS と LS 状態での基準振動を計算し、298 K と $100 \mathrm{~K}$ で赤外・ラマン分光の実験デー夕との比較を行な つている。計算による分子内振動のエントロピー変化は $\Delta S(\mathrm{vib})=19.5 \mathrm{~J} \mathrm{~K}^{-1} \mathrm{~mol}^{-1}$ であった。予想したよりも小さ な值にみえるが、残りは結晶の音響型格子振動のソフト 化に起因するものであり、両者を合わせたものがフォノ ンエントロピー $\Delta S$ (phonon) である。

興味深いことに、1990 年に Gallois ら ${ }^{47)}$ が行なった 構造解析では、これだけ大きなエントロピー変化を伴 う相転移であるにもかかわらず、結晶系と空間群は LS 相と HS 相で同じ斜方晶系 $P b c n(Z=4)$ である。結晶構 造の変化を伴うスピンクロスオーバー錯体も少しは報 告されているが、多くは空間群が変化しない同形転移 (isomorphous transition) である。これもスピンクロスオ ーバーの特徵の 1 つに数えられる ${ }^{3)}$

スピンクロスオーバーを示す錯体は、今日では数多く 知られている。2004 年にスピンクロスオーバー全般に 関する総括的な解説書が、Gütlich と Goodwin 編で出版 された ${ }^{48)}$ 。またスピンクロスオーバーの熱的性質に関し ては、筆者の総説 ${ }^{1,2)}$ とレビュー ${ }^{3,4)}$ を参照されたい。

\section{2. 思い出のスピンクロスオーバー錯体：[Fe"(2- pic) $\left.{ }_{3}\right] \mathrm{X}_{2} \cdot($ solv)}

スピンクロスオーバーは、低スピン (LS) と高スピン (HS) の $2 つ の$ 電子状態のエンタルピー差 $\Delta H$ がエントロ ピー項 $T \Delta S$ で補償され、ギブズエネルギー差 $\Delta G=\Delta H-$ $T \Delta S$ の符合が逆転する現象である。エントロピー源には スピン多重度の変化も当然含まれるが、大きな寄与をす るのは非電子系のフォノンや分子の秩序・無秩序型運動 に起因するエントロピーである。純粋な磁気相転移など と異なり、スピンクロスオーバーは複合効果で起こる転 移現象である。そのため、スピンクロスオーバーは様々 


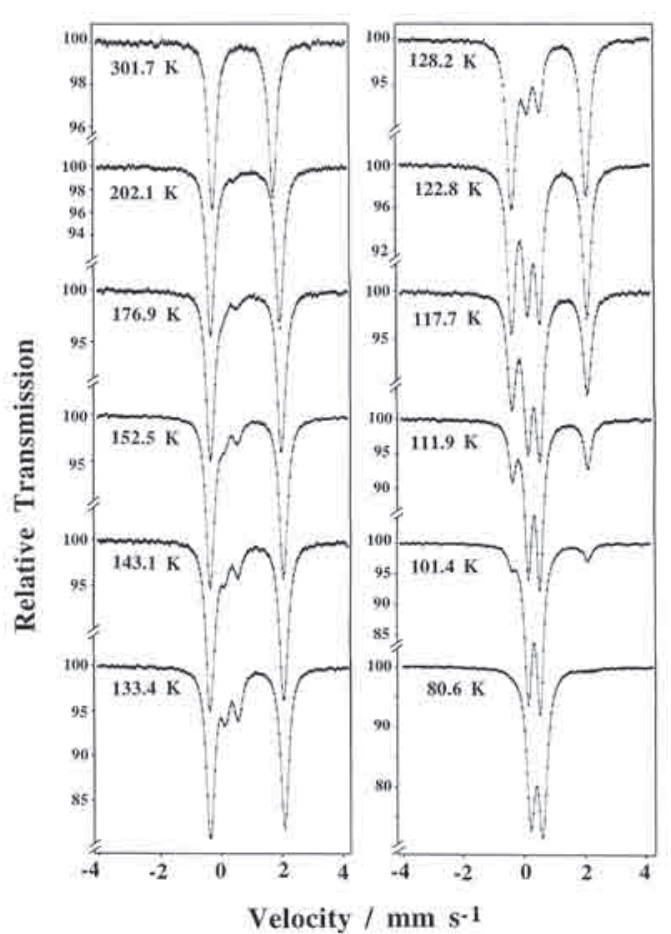

Fig. $16{ }^{57} \mathrm{Fe}$ Mössbauer spectra of $\left[\mathrm{Fe}(2-\mathrm{pic})_{3}\right] \mathrm{Cl}_{2} \cdot \mathrm{C}_{2} \mathrm{H}_{5} \mathrm{OH}$ crystal at various temperatures. ${ }^{52}$

な化学的・物理的要因の影響を受ける ${ }^{49)}$ 。

初めてのスピンクロスオーバー錯体 $\left[\mathrm{Fe}(\mathrm{NCS})_{2}(\mathrm{phen})_{2}\right]$ が報告された 1967 年に、Renovitch と Baker ${ }^{50)}$ がスピン クロスオーバー錯体 $\left[\mathrm{Fe}^{\mathrm{II}}(2-\mathrm{pic})_{3}\right] \mathrm{X}_{2}$ (2-pic : 2-アミノメ チルピリジンまたは 2- ピコリルアミン、 $\mathrm{X}: \mathrm{Cl}, \mathrm{Br}, \mathrm{I})$ の磁気的性質を 1 頁の速報で報告している。塩化物は室 温で HS、 $4.2 \mathrm{~K}$ で LS 状態になり、115 K 近辺で両者の 存在割合が等しくなる。

筆者はスピンクロスオーバー現象に打けるマクロな側 面とミクロな側面の関係に興味を抱き、1974 年に西ド イッの Gütlich 教授のもとに留学し、スピンクロスオー バー錯体 $\left[\mathrm{Fe}(2-\mathrm{pic})_{3}\right] \mathrm{Cl}_{2}$ の ${ }^{57} \mathrm{Fe}$ メスバウアー分光による 研究を行なった。ところが試料合成をしても Renovitch と Baker の論文 ${ }^{50)}$ に記載されている錯体は得られず困 惑したが、合成溶媒を替えることで謎が解けた。この 錯体は溶媒分子を化学量論的に結晶に取り込むことが 判明 ᄂ、 $\left[\mathrm{Fe}(2-\mathrm{pic})_{3}\right] \mathrm{Cl}_{2}$. (solv) (solv $=\mathrm{H}_{2} \mathrm{O}, 2 \mathrm{H}_{2} \mathrm{O}, \mathrm{CH}_{3} \mathrm{OH}$, $\left.\mathrm{C}_{2} \mathrm{H}_{5} \mathrm{OH}\right)$ を得た ${ }^{51)}$ 。筆者は物理化学が専門なので、新 しい錯体を創製するのは苦手だが、 $\left[\mathrm{Fe}(2-\mathrm{pic})_{3}\right] \mathrm{Cl}_{2}$ が様々 な溶媒和物として存在できることをたまたま発見したこ とは、大きな喜びである。代表例として筆者が測定し た $\left[\mathrm{Fe}(2-\mathrm{pic})_{3}\right] \mathrm{Cl}_{2} \cdot \mathrm{C}_{2} \mathrm{H}_{5} \mathrm{OH}$ の ${ }^{57} \mathrm{Fe}$ メスバウアースペクト ルの温度変化を Fig. 16 に示す ${ }^{52)}$ 。 $301.7 \mathrm{~K}$ のスペクトル は HS に特徵的な四重極分裂 $\Delta E_{\mathrm{Q}}(\mathrm{HS})=(1.99 \pm 0.03) \mathrm{mm}$ $\mathrm{s}^{-1}$ のダブレットのみだが、冷却すると内側に別の四重 極分裂ダブレットが現れている。これは LS 状態の四重 極分裂 $\Delta E_{\mathrm{Q}}(\mathrm{LS})$ である。121.5 K で両ダブレットの面積 が等しくなり、80.6 K では LS の四重極分裂ダブレット

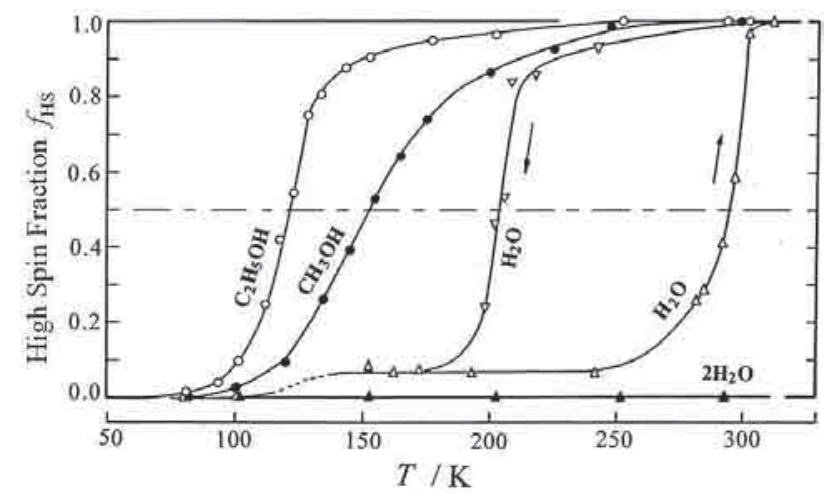

Fig. 17 Temperature dependence of the high-spin area fraction $f_{\mathrm{HS}}$ estimated from ${ }^{57} \mathrm{Fe}$ Mössbauer spectra in the spin crossover complexes with different solvent molecules, $\left[\mathrm{Fe}(2-\mathrm{pic})_{3}\right] \mathrm{Cl}_{2} \cdot(\mathrm{solv})$ [solv $\left.=\mathrm{H}_{2} \mathrm{O}(\triangle, \nabla), 2 \mathrm{H}_{2} \mathrm{O}(\boldsymbol{\Delta}), \mathrm{CH}_{3} \mathrm{OH}(\bigcirc), \mathrm{C}_{2} \mathrm{H}_{5} \mathrm{OH}(\bigcirc)\right]{ }^{51)}$

$\Delta E_{\mathrm{Q}}(\mathrm{LS})=(0.39 \pm 0.02) \mathrm{mm} \mathrm{s}^{-1}$ のみとなる。

Fig. 17 は結晶溶媒が異なるスピンクロスオーバー錯 体 $\left[\mathrm{Fe}(2-\mathrm{pic})_{3}\right] \mathrm{Cl}_{2} \cdot$ (solv) について、メスバウアースペク トルの HS と LS の四重極分裂ピーク面積から決定し た高スピン分率 $f_{\mathrm{HS}}$ の温度変化である ${ }^{51)}$ 。[ $\left.\mathrm{Fe}(2-\mathrm{pic})_{3}\right]$ $\mathrm{Cl}_{2} \cdot \mathrm{C}_{2} \mathrm{H}_{5} \mathrm{OH}$ は $120 \mathrm{~K}$ 近辺でかなり急激なスピンクロス オーバーを示すが、 $\left[\mathrm{Fe}(2-\mathrm{pic})_{3}\right] \mathrm{Cl}_{2} \cdot \mathrm{CH}_{3} \mathrm{OH}$ は $150 \mathrm{~K}$ を 中心に広い温度領域で緩慢に起こっている。1 水和物 $\left[\mathrm{Fe}(2-\mathrm{pic})_{3}\right] \mathrm{Cl}_{2} \cdot \mathrm{H}_{2} \mathrm{O}$ は大きなヒステリシスを示し、加熱 方向は $295 \mathrm{~K}$ で、冷却方向は $204 \mathrm{~K}$ で $f_{\mathrm{HS}}=0.5$ となる。 確認のため四半世紀ぶりに示差熱分析 (DTA) と断熱法 による熱容量測定を行なったところ、これは真正のヒス テリシスではなく、準安定結晶相の存在による見かけの ものであることが判明した ${ }^{53}$ 。 $\left[\mathrm{Fe}(2-\mathrm{pic})_{3}\right] \mathrm{Cl}_{2} \cdot 2 \mathrm{H}_{2} \mathrm{O}$ は全 温度領域で LS 状態のままである。配位に直接関与して いない結晶溶媒が、スピンクロスオーバーの相転移温度 や転移挙動にこれほど大きな影響を与えるのは、水素結 合のネットワークが配位子・対イオン・結晶溶媒の間で 形成されているためである。

Fig. 18 は $\left[\mathrm{Fe}(2 \text {-pic })_{3}\right] \mathrm{Cl}_{2} \cdot \mathrm{C}_{2} \mathrm{H}_{5} \mathrm{OH}$ のモル熱容量である ${ }^{54)}$ 。2つのピークが $114.04 \mathrm{~K}$ と $122.21 \mathrm{~K}$ に観測された。 スピンクロスオーバーが 2 段階で起こることは 1977 年 の時点 ${ }^{51)}$ ではわかっていなかったが、Gütlich ら ${ }^{55)}$ は転 移温度近辺でのメスバウアー分光と磁化率測定を詳しく 行ない、2 段階で起こる最初のスピンクロスオーバー錯 体として報告した。今日では、2段階で相転移が起こる 錯体が幾つか報告されている ${ }^{3)}$ 。Fig. 18 の破線は正常熱 容量であり、相転移温度でスピンクロスオーバーに特徴 的な段差が観測されている。転移エントロピーは $\Delta_{\mathrm{tr}} S=$ $50.6 \mathrm{~J} \mathrm{~K}^{-1} \mathrm{~mol}^{-1}$ であり、スピン多重度に基づくエントロ ピーR $\ln (5 / 1)\left(=13.4 \mathrm{~J} \mathrm{~K}^{-1} \mathrm{~mol}^{-1}\right)$ の 3.8 倍におよんでい る。見上ら ${ }^{56,57)}$ はX 線構造解析を行ない、結晶系は HS 相と LS 相の両相でともに単斜晶系 $P 2_{1} / c(Z=4)$ である が、HS 相では結晶溶媒のエタノール分子が 3 ケ所を 3 : 


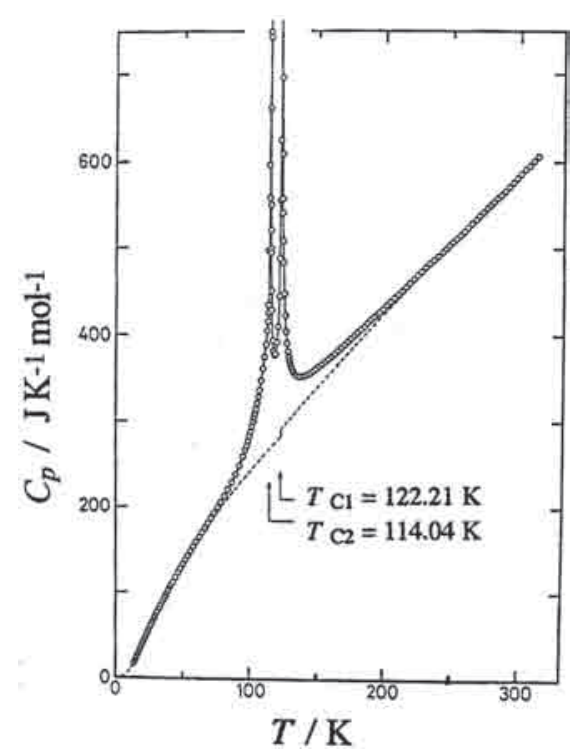

Fig. 18 Molar heat capacity of $\left[\mathrm{Fe}(2-\mathrm{pic})_{3}\right] \mathrm{Cl}_{2} \cdot \mathrm{C}_{2} \mathrm{H}_{5} \mathrm{OH}$. Broken curves indicate the normal heat capacities. ${ }^{54)}$

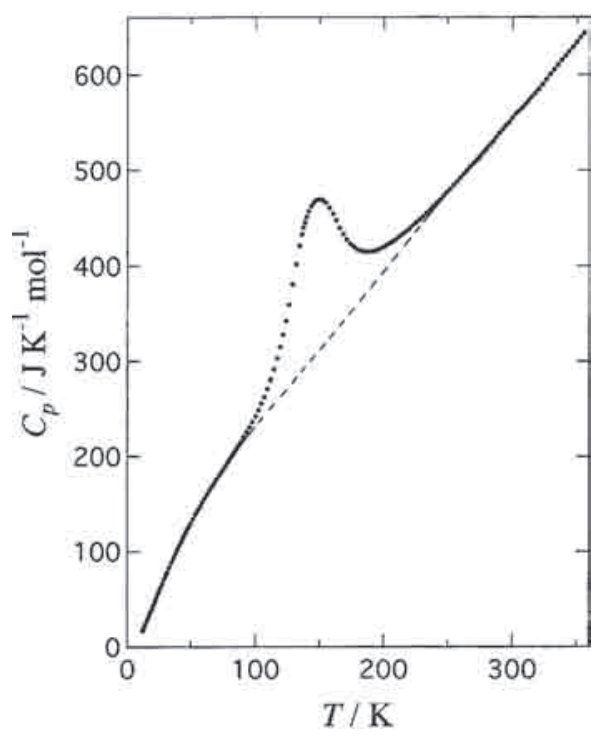

Fig. 19 Molar heat capacity of $\left[\mathrm{Fe}(2-\mathrm{pic})_{3}\right] \mathrm{Cl}_{2} \cdot \mathrm{CH}_{3} \mathrm{OH}$. Broken curve indicates the normal heat capacity. ${ }^{58)}$

2:2の比率で無秩序配向していることを明らかにした。 LS 相では配向は固定されているので、分子配向の無秩 序化に基づくエントロピーは $9.0 \mathrm{~J} \mathrm{~K}^{-1} \mathrm{~mol}^{-1}[=-R(3 / 7)$ $\ln (3 / 7)-2 R(2 / 7) \ln (2 / 7)]$ である。結果として、フォノ ン系からのエントロピーへの寄与は 28.2 (= $50.6-13.4$ 9.0) $\mathrm{J} \mathrm{K}^{-1} \mathrm{~mol}^{-1}$ となり、全体の $56 \%$ に及んでいる。

結晶溶媒のエタノールをメタノールに置き換えると、 スピンクロスオーバー挙動は大きく影響を受ける。Fig. 19 は $\left[\mathrm{Fe}(2-\mathrm{pic})_{3}\right] \mathrm{Cl}_{2} \cdot \mathrm{CH}_{3} \mathrm{OH}$ のモル熱容量 ${ }^{58)}$ であるが、 $150 \mathrm{~K}$ 近辺を頂点とするブロードな転移ピークとなる。 エントロピー変化はエタノール和物より少し大きい 59.5 $\mathrm{J} \mathrm{K}^{-1} \mathrm{~mol}^{-1}$ である。

\section{3. ドメインモデルと協同現象性}

スピンクロスオーバー現象では、非常に狭い温度域で
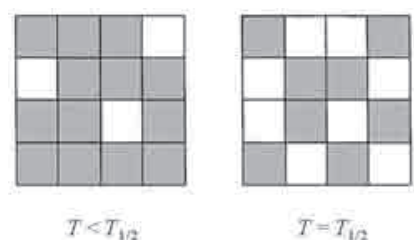

$T=T_{1 / 2}$

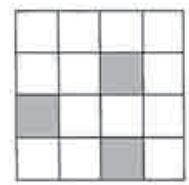

$T>T_{12}$

Low-Spin State $\square$ High-Spin State

Fig. 20 Schematic drawing of the domain model. The crystal lattice is divided by uniform size of domains containing equal number of spin-crossover complexes. $T_{1 / 2}$ is the transition temperature at which the number of LS-domain becomes equal to that of HS-domain. ${ }^{42)}$

急激に転移が完了する場合と、広い温度域で徐々に進行 する場合が知られている。前者の例は 6.1 節で取りあげ た $\left[\mathrm{Fe}(\mathrm{NCS})_{2}(\mathrm{phen})_{2}\right]$ であり、狭い温度範囲で急激に起こ り、1 次相転移の性格をおび、ヒステリシスを伴うこと が多い。後者の例は $\left[\mathrm{Fe}(2-\mathrm{pic})_{3}\right] \mathrm{Cl}_{2} \cdot \mathrm{CH}_{3} \mathrm{OH}$ のように 100 $\mathrm{K}$ 以上の広い温度領域にわたって緩慢に起こる場合であ る。前者を急激型 (abrupt type)、後者を緩慢型 (gradual type) と呼んでいる。しかしどちらの夕イプでも、転移 エントロピーの大きさには大差がない。

スピンクロスオーバー転移がこのように緩慢に起こる 原因を追究する目的で、筆者らは液体における不均一相 の摇らぎに関する Frenkel 理論 ${ }^{59)}$ に基づいたドメインモ デルを提案した ${ }^{42)}$ 。このモデルを模式的に示したのが Fig. 20 である。結晶を均一なサイズの $N$ 個のドメイン に分割し、ドメイン間には相互作用は無いものとする。 各ドメインには $n$ 個のスピンクロスオーバー錯体が存在 し、スピン状態の変換はセル毎に同時に起こるものと仮 定する。アボガドロ定数を $N_{\mathrm{A}}$ とすると、 $N_{\mathrm{A}}=N \cdot n$ の関 係にある。高スピン分率 $f_{\mathrm{HS}}$ を $x$ で置き換えると、温度 Tにおけるギブズエネルギーは

$$
G(x, T)=x G_{\mathrm{H}}+(1-x) G_{\mathrm{L}}+N k T\{x \ln x+(1-x) \ln (1-x)\}
$$

で与えられる。右辺の $G_{\mathrm{H}}$ と $G_{\mathrm{L}}$ は高温相と低温相のギ ブズエネルギー、第 3 項は高スピンと低スピンのドメイ ンの混合に関するエントロピー項である。系の平衡条件 $\partial G /\left.\partial x\right|_{T}=0$ より、

$$
x=\frac{1}{1+\exp (\Delta G / N k T)}
$$

となる。ここで $\Delta G=G_{\mathrm{H}}-G_{\mathrm{L}}$ である。定圧モル熱容量 $C_{p}$ は次式で与えられる。

$$
\begin{aligned}
C_{p} & =\frac{\partial}{\partial T}\left\{x H_{\mathrm{H}}+(1-x) H_{\mathrm{L}}\right\} \\
& =x C_{p, \mathrm{H}}+(1-x) C_{p, \mathrm{~L}}+\frac{\left(H_{11}-H_{\mathrm{L}}\right)^{2} \exp (\Delta G / N k T)}{N k T^{2}\{1+\exp (\Delta G / N k T)\}^{2}}
\end{aligned}
$$




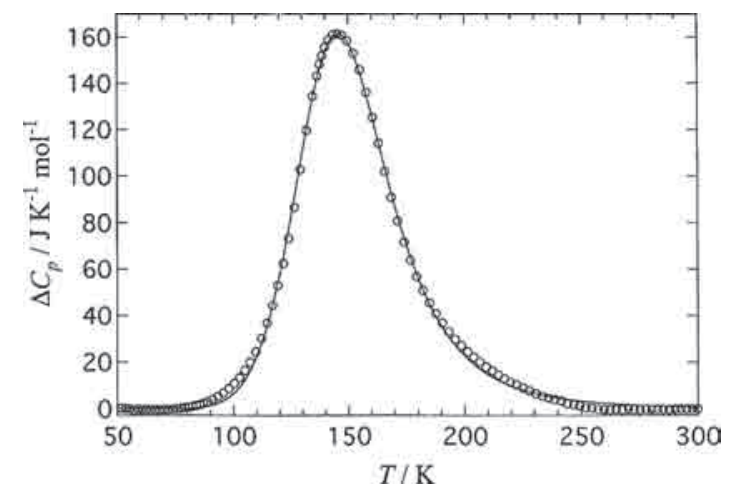

Fig. 21 Excess heat capacity arising from the spin crossover in $\left[\mathrm{Fe}(2-\mathrm{pic})_{3}\right] \mathrm{Cl}_{2} \cdot \mathrm{CH}_{3} \mathrm{OH}{ }^{58)}$

ここで $H$ はモルエンタルピー、 $C_{p, \mathrm{H}}$ と $C_{p, \mathrm{~L}}$ は高温相 $(\mathrm{HS}$ 状態) と低温相（LS 状態）の正常熱容量である。この 式を非線形最小 2 乗法で実測のモル熱容量 $C_{p}$ に最適化 フィットさせるか、あるいは熱容量の相転移部分 $\Delta C_{p}$ を上式の第 3 項にフィットさせ、ドメインの総数 $N$ を 決定し、 $N_{\mathrm{A}}=N \cdot n$ の関係からドメイン内の錯体数 $n$ を決 定するわけである。

このドメインモデルの特徴は、 $n$ が減少するにつれ 熱容量のピークがブロードになり、相転移の協同現象 性が弱くなることである。 $n$ が極端に小さな值 1 とな った場合は、ファント・ホッフ (van't Hoff) の化学平 衡の式と等価になる。ドメインあたりの錯体数 $n$ は $\left[\mathrm{Cr}^{\mathrm{II}} \mathrm{I}_{2}(\mathrm{depe})_{2}\right]^{60)}[$ depe $=1,2$-bis(diethylphosphino)ethane $]$ で 2000、 $\left[\mathrm{Fe}(\mathrm{NCS})_{2}(\mathrm{phen})_{2}\right]^{42)}$ で 95 と大きいが、スピンク ロスオーバーが緩慢に起こる $\left[\mathrm{Fe}^{\mathrm{III}}(\mathrm{acpa})_{2}\right] \mathrm{PF}_{6}{ }^{61)}$ では 5 と 小さくなる。 $\left[\mathrm{Fe}(2-\mathrm{pic})_{3}\right] \mathrm{Cl}_{2} \cdot \mathrm{CH}_{3} \mathrm{OH}$ の場合は、スピンク ロスオーバーに基づく過剩熱容量 $\Delta C_{p}$ が、Fig. 21 に示 したように $n=1.5$ の場合の理論曲線と見事な一致を示 している ${ }^{58)}$ 。このうに小さな值になるのは、協同現 象性が極端に弱いことを示している。熱測定の解析か ら推測されたドメインが実際に存在することを、1990 年に Doan と McGarvey ${ }^{62)}$ は EPR を用いて $\left[\mathrm{Fe}(2-\mathrm{pic})_{3}\right]$ $\mathrm{Cl}_{2} \cdot \mathrm{C}_{2} \mathrm{H}_{5} \mathrm{OH}$ 錯体で検証した。

ドメインモデルは簡単なモデルであるが、スピンクロ スオーバー現象以外の相転移でも広く適用できることが 判明したので、相転移の本質をついたものといえよう。

\section{7. 電荷移動による相転移}

電荷移動が原因で相転移が起こることがある。代表例 として 3 核混合原子価鉄錯体 (7.1 節)、ハロゲン架橋 MMX 型白金複核錯体 (7.2 節)、混合原子価集積型鉄錯 体（7.3 節）、分子間電荷移動に基づく中性イオン性相転 移（7.4節）の熱測定を紹介する。

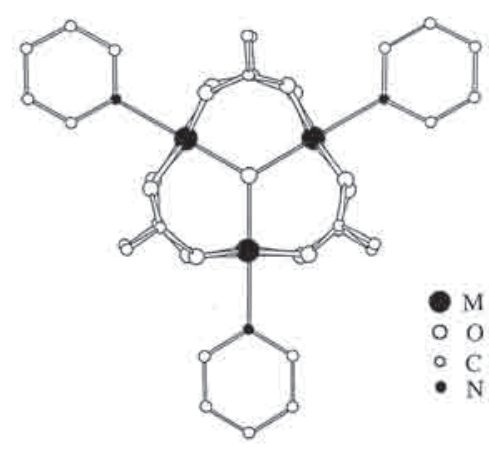

Fig. 22 Molecular structure of the oxo-centered trinuclear basic metal acetate having a formula $\left[\mathrm{M}^{\prime \prime} \mathrm{M}^{\prime \prime \prime}{ }_{2} \mathrm{O}\left(\mathrm{O}_{2} \mathrm{CCH}_{3}\right)_{6}(\mathrm{py})_{3}\right]$ with $D_{3 h}$ symmetry in the valence-detrapped state. ${ }^{64)}$

\subsection{3 核混合原子価鉄錯体 : $\left[\mathrm{Fe} \mathrm{Fe}^{\prime \prime} \mathrm{Fe}_{2} \mathrm{O}^{\mathrm{O}}\left(\mathrm{O}_{2} \mathrm{CCH}_{3}\right)_{6}(\mathrm{p}\right.$ y) $\left.{ }_{3}\right] \cdot($ py)}

最もよく知られた 3 核混合原子価錯体は、Hendrickson らにより報告された $\left[\mathrm{M}^{\mathrm{II}} \mathrm{M}^{\mathrm{III}}{ }_{2} \mathrm{O}\left(\mathrm{O}_{2} \mathrm{CCH}_{3}\right)_{6} \mathrm{~L}_{3}\right]$. (solv) ( $\mathrm{M}$ : $\mathrm{Fe}$ または Mn、L : 中性の単座配位子、solv：溶媒分子) である。これらの錯体分子では、金属クラスターの電 子状態が分子振動と強い相関をもっている。そのため 分子が凝集して結晶になると、分子間相互作用の影響 を受け、低温で原子価が固定された状態いわゆる原子 価捕捉状態 (valence-trapped state) から、高温での原子価 摇動状態 (valence-detrapped state) へ移行する ${ }^{63}$ ) 2 Fig. 22 は原子価摇動状態にある室温での 3 核混合原子価錯体 $\left[\mathrm{Fe}_{3} \mathrm{O}\left(\mathrm{O}_{2} \mathrm{CCH}_{3}\right)_{6}(\mathrm{py})_{3}\right]$ の分子構造であり、3つの鉄原子 を頂点とする三角形 $\mathrm{Fe}_{3} \mathrm{O}$ は正三角形である ${ }^{64)} 。 \mathrm{Fe}^{2+}$ は $\mathrm{Fe}^{3+}$ より電子が 1 つ多いので、 3 価の鉄イオン 2 個と 2 価の鉄イオン 1 個からなる混合原子価錯体は、3 価の鉄 イオン 3 個と過剩な $\mathrm{d}$ 電子 1 個からなる系と同じとみな せる。真空中にある自由な分子では、過剩な $\mathrm{d}$ 電子が 3 つの金属イオンのどこに所属してもエネルギー的に等価 なので、金属クラスターの電子エネルギーは 3 重に縮重 している。しかし、過剩な $\mathrm{d}$ 電子はクラスターの伸縮 振動と振電相互作用 (vibronic interaction)を通してカップ ルしており、擬ヤーン・テラー歪み (pseudo Jahn-Teller distortion) を生じて、3つの断熱ポテンシャル $E_{i}\left(q, \theta_{0}\right)$ $(i=1,2,3)$ に縮重が解ける (Fig. 23) $)^{65)}$ 。q は正三角形か らの歪みの大きさを表す極座標であり、正三角形は $q=$ 0 、それ以外は $q \neq 0$ である。 $\theta$ は方向を表す極座標で、 $\mathrm{M}-\mathrm{O}$ 結合は $\theta=0 、 2 \pi / 3 、 4 \pi / 3$ に対応する。Fig. 23 は $\theta=$ 0 の断面を表している。熱容量測定で決まる熱エネルギ 一は電子エネルギーと比べて非常に小さいので、断熱ポ テンシャルの基底準位だけを考えればよい。興味深いこ とに、神原らの理論 ${ }^{65}$ ではパラメーター $\Delta\left(=\kappa \omega / \lambda^{2}\right)$ の 大きさに依存して、断熱ポテンシャル曲面は Fig. 23 に 示したように 3 種類に分類される。ここで $\kappa$ は歪みモ

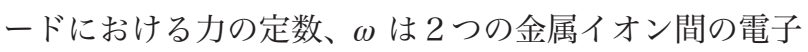



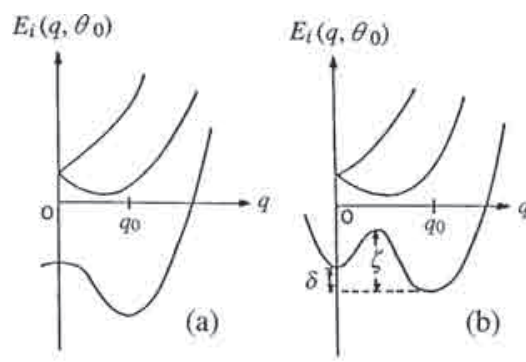

$0<\Delta<2 / 3$

1st type
$2 / 3<\Delta<0.765$ 2nd type

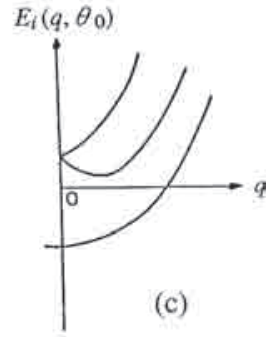

$0.765<\Delta$ 3rd type

Fig. 23 Three types of the energy profiles $E_{i}\left(q, \theta_{0}\right)$ for different values of $\Delta$ along the direction of a $\mathrm{M}-\mathrm{O}$ bond $\left(\theta_{0}=0,2 \pi / 3\right.$, or $2 \pi / 3$ ), where $q$ is the amplitude of distortion. ${ }^{65}$
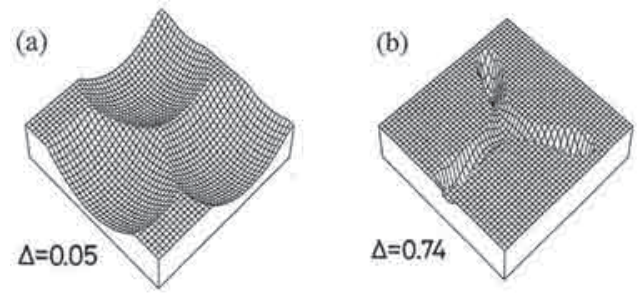

Fig. 24 3D-drawing of the adiabatic potential energy surface for the ground electronic states of a mixed-valence $\mathrm{M}_{3} \mathrm{O}$ complex calculated for two different values of (a) $\Delta=0.05$ and (b) $\Delta=$ $0.74 .{ }^{66)}$

の移動積分、 $\lambda$ は $\mathrm{d}$ 電子と歪みのカップリング定数であ る。 $\Delta$ の值が 0 から 2/3のときは、Fig. 23aのように同 じ深さのポテンシャル極小が $\theta=0 、 2 \pi / 3 、 4 \pi / 3$ の 3 ケ所 にできる。すなわちエネルギーの等しい 3 つの二等辺三 角形である。 $2 / 3<\Delta<0.765$ (Fig. 23b) では、これら 3 つの二等辺三角形に加えて、 $q=0$ にも極小が出現する。

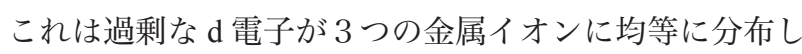
た正三角形に対応する。他方、 $0.765<\Delta$ になると、均 等な正三角形のみが安定な構造となる (Fig. 23c)。Fig. 23a と Fig. 23b を、3 次元的に描いたのが Fig. 24 である ${ }^{66)}$ 。それぞれ3つと4つのポテンシャル極小が視覚化さ れている。

ここまでの説明は自由分子に関するものである。分子 が凝集して結晶を形成すると、分子間相互作用による環 境効果のため特定の極小がより低いエネルギーをもつよ うになる。そのために、静的な二等辺三角形の錯体が低 温で形成される。昇温すると、エネルギーの高い他の二 等辺三角形や、場合によっては正三角形の錯体が実現す る確率が増え、大振幅の変形運動が励起される。そのた め分子の環境は平均化され、相転移の高温側では、錯体 分子はこれらの形状を動的に実現するようになる。こ のような分子の配向に関する運動が相転移で励起され ると、予想されるエントロピーの増分は $R \ln 3$ (Fig. 23a, Fig. 24a) あるいは $R \ln 4$ (Fig. 23b, Fig. 24b) である。

Fig. 25 は筆者らが測定した $\left[\mathrm{Fe}_{3} \mathrm{O}\left(\mathrm{O}_{2} \mathrm{CCH}_{3}\right)_{6}(\mathrm{py})_{3}\right] \cdot(\mathrm{py})$ 結晶のモル熱容量である ${ }^{67,68)}$ 。 4 つの相転移が観測され

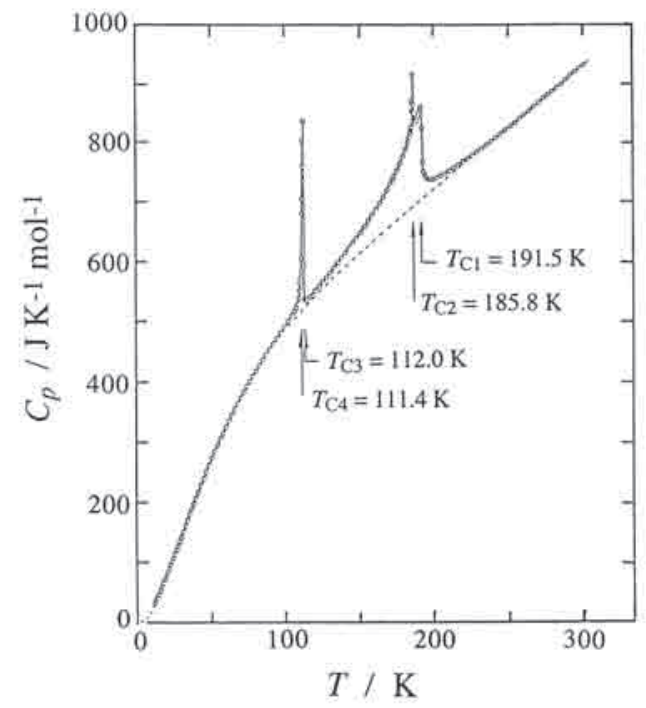

Fig. 25 Molar heat capacity of the mixed-valence complex $\left[\mathrm{Fe}^{\mathrm{e}} \mathrm{Fe} \mathrm{II}_{2}^{\mathrm{II}} \mathrm{O}\left(\mathrm{O}_{2} \mathrm{CCH}_{3}\right)_{6}(\mathrm{py})_{3}\right] \cdot(\mathrm{py})$. Broken curve indicates the normal heat capacity. ${ }^{67,68)}$

たが、大きく分けると $111 \mathrm{~K}$ 近傍の 1 次相転移と 191.5 $\mathrm{K}$ の高次相転移である。興味深いことに、111 K は ${ }^{57} \mathrm{Fe}$ メスバウアースペクトル ${ }^{63)}$ に平均原子価による四重極 分裂が現れる温度に一致し、191.5 K は平均原子価のみ になる温度である。熱容量とメスバウアー分光での特 異温度が符合していることから、Fig. 25 でみられる相 転移は分子内電荷移動に起因すると考えられる。図中の 破線は正常熱容量であり、相転移に基づくエントロピ 一変化は $\Delta S=(30.6 \pm 0.8) \mathrm{J} \mathrm{K}^{-1} \mathrm{~mol}^{-1}$ であった。金属ク ラスターの大振幅の運動に基づくエントロピーの増分 は、上述のように $R \ln 3\left(=9.1 \mathrm{~J} \mathrm{~K}^{-1} \mathrm{~mol}^{-1}\right)$ あるいは $R \ln$ $4\left(=11.5 \mathrm{~J} \mathrm{~K}^{-1} \mathrm{~mol}^{-1}\right)$ なので、実測の転移エントロピーは 予想をはるかに超えた值である。溶媒分子が存在しな い $\left[\mathrm{Fe}_{3} \mathrm{O}\left(\mathrm{O}_{2} \mathrm{CCH}_{3}\right)_{6}(\mathrm{py})_{3}\right]$ では電荷移動を示さないことか $ら^{63)}$ 、大きな転移エントロピーの原因は溶媒分子にあ りそうだと推測できる。平均原子価状態にある室温での $\left[\mathrm{Fe}_{3} \mathrm{O}\left(\mathrm{O}_{2} \mathrm{CCH}_{3}\right)_{6}(\mathrm{py})_{3}\right]$. (py) の結晶構造を模式的に示した のが Fig. 26 である ${ }^{64)}$ 。空間群は $R 32$ で、結晶学的 $C_{3}$ 軸 がクラスター $\mathrm{Fe}_{3} \mathrm{O}$ の酸素原子を貫いて通っている。 3 核錯体と溶媒分子ピリジンは $C_{3}$ 軸にそって交互積層し ている。ところがピリジンの分子面内を $C_{3}$ 軸が通って いるため、 $C_{3}$ 回転対称の要請をみたすためには、ピリ ジン分子は $C_{3}$ 軸まわりに $2 \pi / 3$ 間隔で少なくとも 3 つの 配向に関する乱れが存在しなければならないことにな る。さらに $R 32$ の要請から、3 回軸に垂直な 2 回軸が存 在する。ピリジン分子の 5 個の $\mathrm{H}$ 原子を重水素置換し たピリジン $-d_{5}$ を有する錯体の ${ }^{2} \mathrm{H}$ NMR に基づき、ピリ ジン分子の運動状態が研究された ${ }^{64)} 。{ }^{2} \mathrm{H}$ NMR スペクト ルは、ピリジン分子の窒素原子が $C_{3}$ 軸上にこない $1 、 2 、 3 、$ 4 の 4 つの配向 (Fig. 27) を取ると仮定したモデルに最適 化された。そうだとすると、溶媒分子ピリジンは $C_{3}$ 軸 


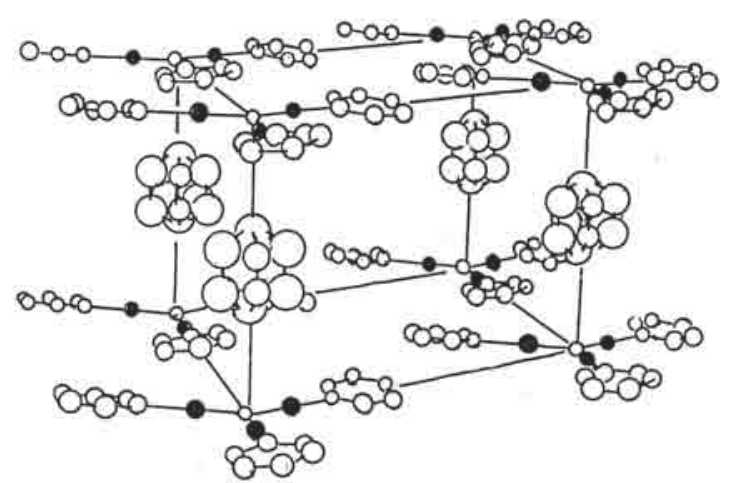

Fig. 26 Schematic drawing of the crystal structure of $\left[\mathrm{Fe}_{3} \mathrm{O}\left(\mathrm{O}_{2} \mathrm{CCH}_{3}\right)_{6}(\mathrm{py})_{3}\right]$. (py). The acetato ligands are not shown for clarity. Crystallographic $\mathrm{C}_{3}$ axis runs through the central oxygen atoms of the $\mathrm{Fe}_{3} \mathrm{O}$ complexes. ${ }^{64)}$

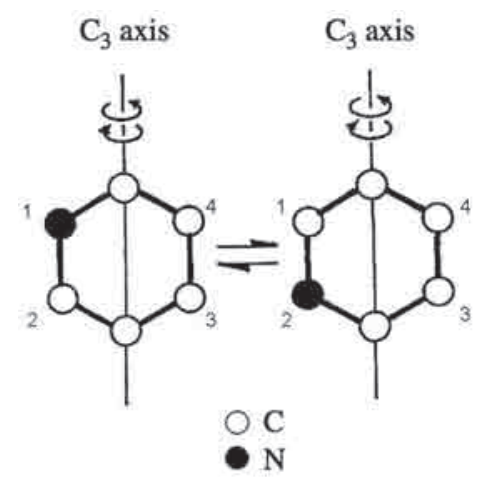

Fig. 27 Orientational disordering of the solvate molecule pyridine in the crystal lattice of $\left[\mathrm{Fe}_{3} \mathrm{O}\left(\mathrm{O}_{2} \mathrm{CCH}_{3}\right)_{6}(\mathrm{py})_{3}\right] \cdot(\mathrm{py})$. The molecular plane of the pyridine jumps among three positions about the crystallographic $C_{3}$ axis. In each planar position, the pyridine solvate molecule liberates among four positions $(1,2.3$, and 4$)$, where in each of these positions two carbon atoms are on the $C_{3}$ axis. $^{64)}$

まわりで 3 通りの配向があり、それぞれの場合に分子面 内で 4 つの再配向運動をするので、エントロピーとして は $R \ln (3 \times 4)\left(=20.7 \mathrm{~J} \mathrm{~K}^{-1} \mathrm{~mol}^{-1}\right)$ が期待される。錯体分子 内での原子価摇動で、3 種類の二等辺三角形の $\mathrm{Fe}_{3} \mathrm{O}$ コ アが等確率で出現する場合のエントロピー $R \ln 3$ (=9.1 J $\mathrm{K}^{-1} \mathrm{~mol}^{-1}$ ) との和は $29.8 \mathrm{~J} \mathrm{~K}^{-1} \mathrm{~mol}^{-1}$ となり、実測值 (30.6 $\pm 0.8) \mathrm{J} \mathrm{K}^{-1} \mathrm{~mol}^{-1}$ をよく再現する。このことから、原子 価搖動に基づく大振幅の変形運動と溶媒和分子の再配向 運動のカップリングが相転移のメカニズムであることを 明らかにした。この結論は、他の多くの錯体にもあては まっている ${ }^{69)}$ 。

\section{2. 八ロゲン架橋 $\mathrm{MMX}$ 型白金複核錯体:}

\section{$\left[\mathrm{Pt} \mathrm{Pt}^{\mathrm{III}}\left(\mathrm{RCS}_{2}\right)_{4} \mathrm{l}\right]$}

金属間結合と混合原子価を有するハロゲン架橋白金複 核錯体いわゆる MMX 型擬 1 次元錯体 $\left[\mathrm{Pt}^{\mathrm{II}} \mathrm{Pt}^{\mathrm{III}}\left(\mathrm{RCS}_{2}\right)_{4} \mathrm{I}\right]$ $\left(\mathrm{R}:-\mathrm{C}_{n} \mathrm{H}_{2 n+1}\right)$ は、複核ユニット内の電荷分布の多様性か ら多彩な電子状態の可能性が指摘されている。北川ら 70-72) は電気伝導率、熱電能、磁化率の測定から、混合

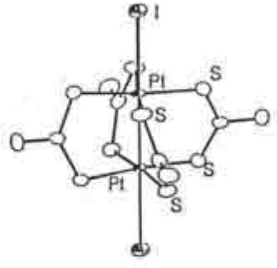

$\mathrm{LT}$ 相 $(\mathrm{C} 2 / c)$

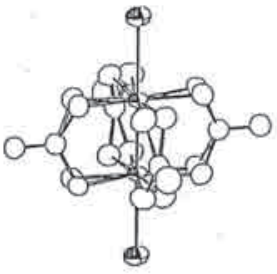

HT 相 $(A 2 / m)$
Fig. 28 A part of 1D arrangement of the halogen-bridged mixed-valence complex $\left[\mathrm{Pt}_{2}\left(\mathrm{CH}_{3} \mathrm{CS}_{2}\right)_{4} \mathrm{I}\right]$. In the HT-phase, two conformational disorders of each ligand are drawn with equal probalility. ${ }^{73)}$

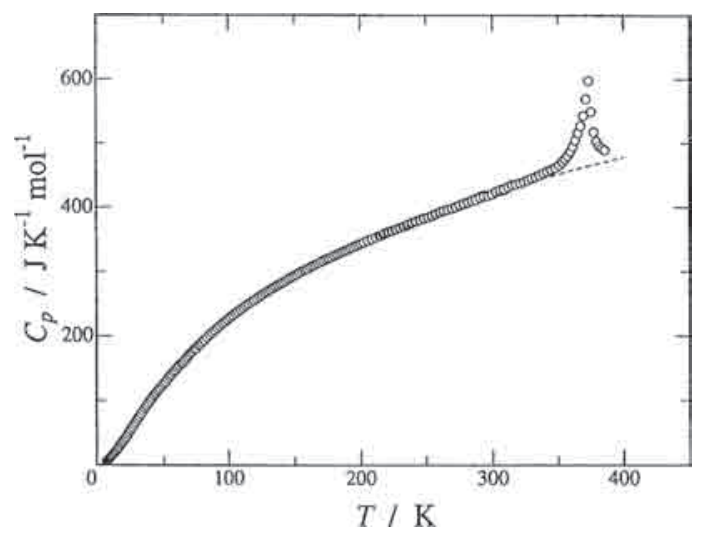

Fig. 29 Molar heat capacity of $\left[\mathrm{Pt}_{2}\left(\mathrm{CH}_{3} \mathrm{CS}_{2}\right)_{4}\right]$. The broken curve implies normal heat capacity. ${ }^{74)}$

原子価錯体 $\left[\mathrm{Pt}_{2}\left(\mathrm{CH}_{3} \mathrm{CS}_{2}\right)_{4} \mathrm{I}\right]$ が $300 \mathrm{~K}\left(T_{\mathrm{SM}}\right)$ あたりで半導 体 $(\mathrm{S})$ から金属的 $(\mathrm{M})$ なふるまいに変化し、360 K $\left(T_{\mathrm{trs}}\right)$ 近辺で 1 次相転移を示すことを見いだした。鳥海ら ${ }^{73)}$ は X 線構造解析により、 $T_{\mathrm{trs}}=365 \mathrm{~K}$ で空間群が $C 2 / c$ か ら $A 2 / m$ に変化することを明らかにした (Fig. 28)。 $T_{\mathrm{trs}}$ 以 下の低温 (LT) 相では 4 つの架橋配位子 $\mathrm{CH}_{3} \mathrm{CS}_{2}{ }^{-}$が $\mathrm{Pt}$ $\mathrm{Pt}$ 軸のまわりで規則正しいらせん状配列をしているが、 $T_{\text {trs }}$ 以上の高温 $(\mathrm{HT})$ 相では各々の配位子が時計回りと反 時計回りの 2 つ配向を無秩序に取っている。筆者ら 74) は本錯体の熱容量を断熱法で測定し、Fig. 29 のよう な結果を得た。空間群が変化する相転移は $373.4 \mathrm{~K}$ に明 確なピークとして観測されたが、 $300 \mathrm{~K}$ 近辺で起こるこ とが指摘された半導体金属転移や、80 K 近辺に予想さ れたスピンパイエルス的な相転移は観測されなかった。 $373.4 \mathrm{~K}$ の相転移は顕著であるが、転移エントロピーは $\Delta_{\mathrm{trs}} S=(5.25 \pm 0.07) \mathrm{J} \mathrm{K}^{-1} \mathrm{~mol}^{-1}$ しかなかった。構造解析で 明らかになった配位子の配向無秩序運動が、4つの配位 子で独立に起こっている場合、期待されるエントロピー は $4 \times R \ln 2=23.05 \mathrm{~J} \mathrm{~K}^{-1} \mathrm{~mol}^{-1}$ である。ところが実測值 はこの值の四分の一に対応する $R \ln 2=5.75 \mathrm{~J} \mathrm{~K}^{-1} \mathrm{~mol}^{-1}$ にきわめて近いものである。この事実は、 $\mathrm{CH}_{3} \mathrm{CS}_{2}^{-}$配位 子の $\mathrm{Pt}-\mathrm{Pt}$ 軸まわりの運動は独立ではなく、4つがシ ンクロナイズしていることを示唆している。構造解析は 分子配列の空間平均と分子運動の時間平均を検出するの が特徵なので、配位子の配向無秩序運動が独立かシンク 


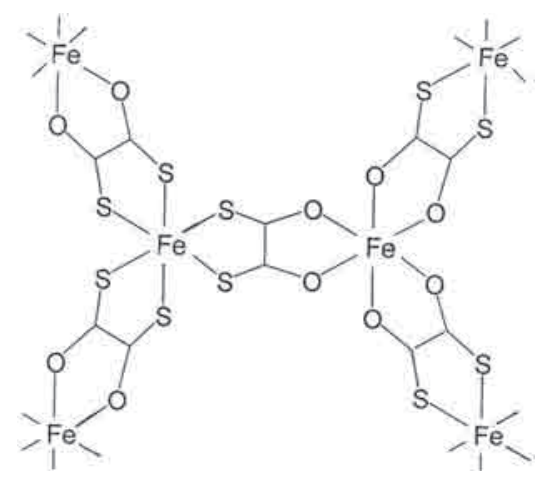

Fig. 30 Schematic drawing of the dto-bridged network structure in

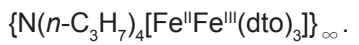

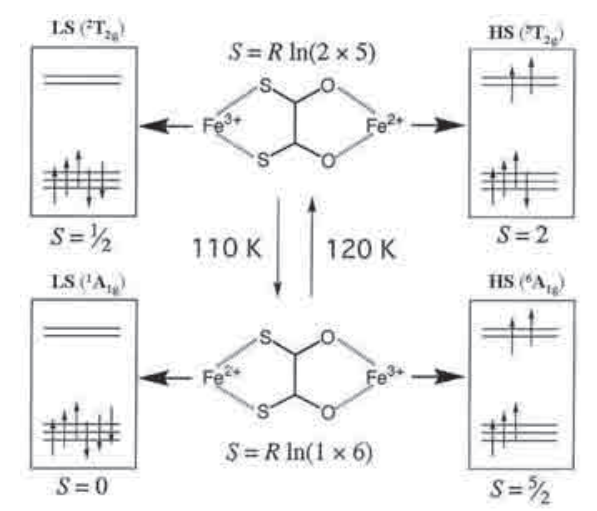

Fig. 31 The spin-state conversion due to electron transfer in $\{\mathrm{N}(n-$ $\left.\left.\left.\mathrm{C}_{3} \mathrm{H}_{7}\right)_{4}\left[\mathrm{Fe}^{\prime \prime} \mathrm{Fe} \text { "'I(dto }\right)_{3}\right]\right\}_{\infty}$. It should be remarked that symbol $S$ is used both for the spin quantum number and for the entropy due to the spin multiplicity. ${ }^{76)}$

ロナイズしているかを区別できないが、エントロピーに は両者の違いを明確に区別できる利点がある。

\section{3. 混合原子価集積型鉄錯体： $\left.\mathrm{N}\left(\mathrm{C}_{3} \mathrm{H}_{7}\right)_{4}\left[\mathrm{Fe} \mathrm{F}^{\prime \prime} \mathrm{Fe} \mathrm{F}^{\text {III(dto }}\right)_{3}\right]$}

4 章で取りあげた 2 次元集積型異種金属錯体の架橋配 位子であるシュウ酸イオン $\mathrm{ox}^{2-}\left(=\mathrm{C}_{2} \mathrm{O}_{4}{ }^{2-}\right)$ を、非対称な ジチオシュウ酸イオン $\mathrm{dto}^{2-}\left(=\mathrm{C}_{2} \mathrm{O}_{2} \mathrm{~S}_{2}{ }^{2-}\right)$ で置き換えた鉄 の混合原子価錯体 $\left\{\mathrm{N}_{(}\left(\mathrm{C}_{3} \mathrm{H}_{7}\right)_{4}\left[\mathrm{Fe}^{\mathrm{II}} \mathrm{Fe} \mathrm{e}^{\mathrm{III}}(\mathrm{dto})_{3}\right]\right\}_{\infty}$ が電荷移動 を伴った興味深い現象を示すことを小島ら ${ }^{75,76)}$ が見い だした。この錯体には 2 価と 3 価の鉄が存在し、6 個の 酸素原子で囲まれた $\left[\mathrm{FeO}_{6}\right]$ サイトとイオウ原子で囲ま れた $\left[\mathrm{FeS}_{6}\right]$ サイトから成っている (Fig. 30)。配位子場は $\left[\mathrm{FeO}_{6}\right]$ サイトより $\left[\mathrm{FeS}_{6}\right]$ サイトの方がはるかに強いの で、鉄の酸化数とは無関係に $\left[\mathrm{FeS}_{6}\right]$ サイトの鉄は低スピ ン (LS)、 $\left[\mathrm{FeO}_{6}\right]$ サイトは高スピン (HS) となる。Fig. 31 に示したように ${ }^{76)}$ 、室温では $\left[\mathrm{FeS}_{6}\right]$ サイトは LS の $\mathrm{Fe}^{3+}$

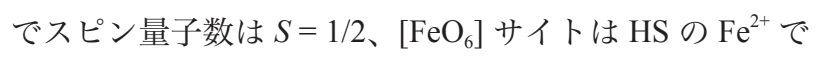
スピン量子数は $S=2$ である。冷却すると $110 \mathrm{~K}$ 近辺で $\left[\mathrm{FeO}_{6}\right]$ サイトから $\left[\mathrm{FeS}_{6}\right]$ サイトへ電荷移動が起こり、そ れぞれのサイトで鉄原子の酸化数が変化する。すなわち、 $\left[\mathrm{FeS}_{6}\right]$ サイトは $\mathrm{LS}$ の $\mathrm{Fe}^{2+}(S=0) 、\left[\mathrm{FeO}_{6}\right]$ サイトは $\mathrm{HS}$ の $\mathrm{Fe}^{3+}(S=5 / 2)$ となる。昇温すると $120 \mathrm{~K}$ 近辺で可逆的に 逆方向への電荷移動が起こる。相転移によりスピン多重

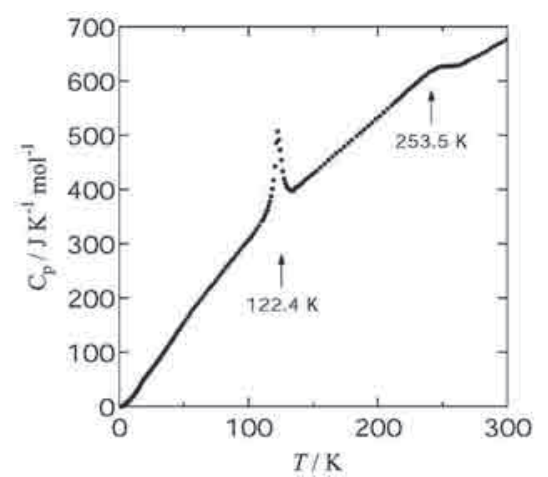

Fig. 32 Molar heat capacity of the mixed-valence complex $\{\mathrm{N}(n-$ $\left.\left.\mathrm{C}_{3} \mathrm{H}_{7}\right)_{4}\left[\mathrm{Fe} \mathrm{Fe}^{\prime \prime} \mathrm{Fe}(\mathrm{dto})_{3}\right]\right\}_{\infty}{ }^{77)}$

度が低温相の $6(=1 \times 6)$ から高温相の $10(=2 \times 5)$ に変化 するので、スピンクロスオーバー現象のような印象を与 えるが、それは誤解である。電子数が変化しない同一の 酸化状態で、電子配置が温度、圧力、光照射などで変化 する現象がスピンクロスオーバーである。ともあれたい へん興味深い相転移である。

筆者ら ${ }^{77)}$ はこの錯体のモル熱容量を断熱型熱量計で 決定し、Fig. 32 の結果を得た。1 22.4 K にスパイク状の ピーク、253.5 K になだらかなピーク、この図ではわか りにくいが $7 \mathrm{~K}$ にもなだらかな熱容量のふくらみが観測 された。253.5 K の熱異常は、類似錯体 ${ }^{29,78-80)}$ の熱容量 測定から、陽イオン $\mathrm{N}\left(\mathrm{C}_{3} \mathrm{H}_{7}\right)_{4}^{+}$の秩序・無秩序運動に基 づく相転移であると推察できる。7 K の熱異常は、低温 相でも常磁性である $\left[\mathrm{FeO}_{6}\right]$ サイトの $\mathrm{Fe}^{3+}$ のスピン $(S=$ $5 / 2$ ) が強磁性的に秩序化する磁気相転移である。これら 2つの熱異常については、ここでは立ち入らないことに する。

$122.4 \mathrm{~K}$ の熱異常は、電荷移動に基づく相転移に起因 している。転移エントロピーは $\Delta_{\mathrm{trs}} S=9.20 \mathrm{~J} \mathrm{~K}^{-1} \mathrm{~mol}^{-1}$ で あった。スピン多重度に基づくエントロピー変化は、 Fig. 31 より $R \ln (10 / 6)=4.25 \mathrm{~J} \mathrm{~K}^{-1} \mathrm{~mol}^{-1}$ なので、 $4.95 \mathrm{~J}$ $\mathrm{K}^{-1} \mathrm{~mol}^{-1}$ だけ余分の寄与があることになる。その原因 として電子の軌道角運動量の寄与と金属一配位子の骨格 振動の寄与の 2 つ可能性を検討する必要がある。結晶 場対称が $O_{h}$ と仮定した場合の結晶場項は、Fig. 31 に示 したように、高温相では $\left[\mathrm{FeS}_{6}\right]$ サイトは $\mathrm{Fe}^{\mathrm{III}}(\mathrm{LS})$ の $^{2} \mathrm{~T}_{2 \mathrm{~g}}$ で $\left[\mathrm{FeO}_{6}\right]$ サイトは $\mathrm{Fe}^{\mathrm{II}}(\mathrm{HS})$ の ${ }^{5} \mathrm{~T}_{2 \mathrm{~g}}$ である。低温相は両サ イトとも $\mathrm{A}_{\mathrm{gg}}$ 基底項なので、軌道角運動量の変化が相転 移エントロピーに及ぼす寄与は $\Delta S($ orbital $)=R \ln [(3 \times 3) /$ $(1 \times 1)]=18.27 \mathrm{~J} \mathrm{~K}^{-1} \mathrm{~mol}^{-1}$ になる。しかし実際の結晶で は、鉄原子が置かれている配位子場は立方対称 $O_{\mathrm{h}}$ より 低いので、軌道縮重は解けている。たと元ば正方対称場 $D_{4 h}$ や 3 回対称場 $D_{3 d}$ になると、立方対称場 $O_{h}$ の基底項

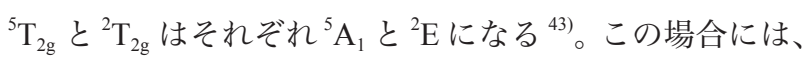
軌道縮重に関するエントロピーは $\Delta S($ orbital $)=R \ln [(2 \times$ $1) /(1 \times 1)]=5.76 \mathrm{~J} \mathrm{~K}^{-1} \mathrm{~mol}^{-1}$ に減少する。この值は実測值 
からスピン多重度 の寄与を差し引い た過剰部分 $4.95 \mathrm{~J}$ $\mathrm{K}^{-1} \mathrm{~mol}^{-1}$ にかなり 近い。
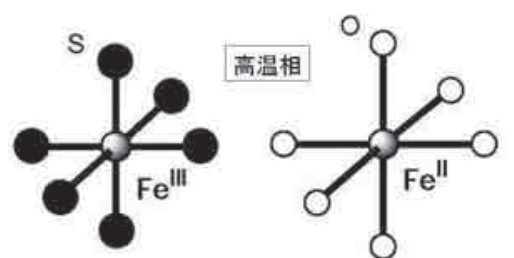

しかし、さらに 結晶場の対称が低 くなると ${ }^{2} \mathrm{E} も$ 軌 道縮重が解け、電 子スピンからの寄 与はスピンオンリ ーとなるので、別 の原因を検討する 必要がある。それ が格子振動、とり

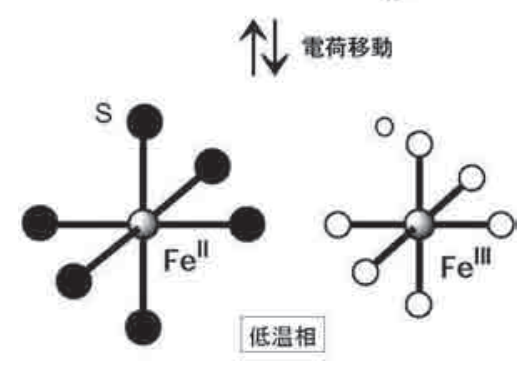

Fig. 33 Schematic drawing of the relationship between charge-transfer and interatomic distances.
わけ金属原子 $(\mathrm{M})$

と配位子 (L) からなる骨格振動である。振動エントロ ピーの大きさは原子間距離 $r(\mathrm{M}-\mathrm{L})$ に依存する。他方、 $r(\mathrm{M}-\mathrm{L})$ は金属元素のスピン状態と酸化状態に大きく依 存する。スピンクロスオーバーの場合は、金属原子の酸 化数は相転移で変化しないので、結合距離の劇的な変化 はスピン状態の変化が原因である。本錯体の場合は、相 転移で電荷移動を伴うので、r(M-L) の変化は酸化数の 変化に起因している。6 配位構造の低スピン鉄錯体の典 型的なイオン半径は、 2 価のとき 75 pm、3 価のとき 69 $\mathrm{pm}$ と報告されている ${ }^{81)}$ 。つまり金属原子と配位子の間 の距離は、酸化数が大きいほど短いことになる。Fig. 33 に模式的に示したように、昇温方向の相転移で $r(\mathrm{M}-\mathrm{L})$ は $\left[\mathrm{FeO}_{6}\right]$ サイトで $13.5 \mathrm{pm}$ 長くなるが、 $\left[\mathrm{FeS}_{6}\right]$ サイトで は逆に $6 \mathrm{pm}$ 短くなることが、糸井ら ${ }^{82)}$ の構造解析で明 らかになっている。つまり相転移に際して、骨格振動の エントロピーは $\left[\mathrm{FeO}_{6}\right]$ サイトでは高温相の方が大きい のでプラスの寄与をするが、 $\left[\mathrm{FeS}_{6}\right]$ サイトでは高温相の 方がエントロピーが小さいので、マイナスの寄与をする ことがわかる。両サイトの寄与が相殺すると、骨格振動 のエントロピーは見かけ上表に出てこないことになる。 本錯体の場合、配位子の相対原子質量が酸素 (15.999) と イオウ (32.065) で大きく異なるため、骨格振動のエント ロピーの相殺が不完全で、4.95 $\mathrm{J} \mathrm{K}^{-1} \mathrm{~mol}^{-1}$ の過剩エント ロピーが生じたとも考えられる。

\section{4. 中性イオン性相転移：TTF-CA}

有機電荷移動錯体を電子供与体 D と受容体 A の積層 の仕方で大きく分類すると、分離積層型と交互積層型に なる。前者は電気伝導体となることが多く、場合によっ ては超伝導体となる。それに対して後者は絶縁体あるい は半導体となる。また電荷移動度 $\rho$ の大きさでの分類で は、 $\rho<0.5$ のときは擬似的に中性、 $\rho>0.5$ の場合はイ
オン性とみなして いる。交互積層型 の電荷移動錯体の 中には、中性イオ ン性転移（NI 転 移)を示すものが ある。

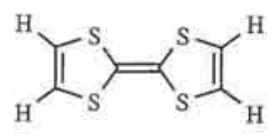

TTF

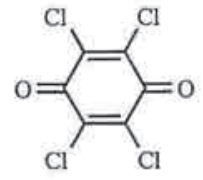

$\mathrm{CA}$
Fig. 34 Molecular structure of TTF and CA.

中性イオン性転移は压力誘起で起こることが多いが、 まれに温度変化で起こる例も存在する。初めての例は テトラチアフルバレン $(\mathrm{TTF})$ と $p$-クロラニル $(\mathrm{CA})$ から なる電荷移動錯体 TTF-CA (Fig. 34) である。Torrance ら ${ }^{83)}$ は可視、赤外、ラマン分光に基づき TTF-CA が $84 \mathrm{~K}$ でNI 転移を示すことを見いだした。高温相は電荷移動 度が $\rho \approx 0.3$ の中性、低温相は $\rho \approx 0.7$ のイオン性である ${ }^{84,85)}$ 。イオン性の低温相では、D 分子と A 分子が積層方 向に沿って ( ...-D-A-D-A- -...) のようなペアリングをし ていることが判明した。

TTF-CA は試料の合成法の違いにより異なる結晶多形 が生じる。筆者らは異なる合成法で調整した試料の熱 容量測定を行なったが、TTF と CA を共昇華させて作製 した試料が一番大きな相転移を示した。Fig. 35 は共昇 華法で得た TTF-CA 結晶のモル熱容量である ${ }^{86)}$ 。 $82.5 \mathrm{~K}$ に NI 転移に基づく鋭いピークが観測された。転移エン トロピー $\Delta_{\mathrm{trs}} S=(6.12 \pm 0.06) \mathrm{J} \mathrm{K}^{-1} \mathrm{~mol}^{-1}$ はかなり大きく、 $R \ln 2$ (= $\left.5.76 \mathrm{~J} \mathrm{~K}^{-1} \mathrm{~mol}^{-1}\right)$ に近い值なので、秩序・無秩序 型の相転移機構が予期される。しかし中性の高温相での $\mathrm{X}$ 線構造解析 ${ }^{87)}$ や中性子線回折 ${ }^{88)}$ では、TTF 分子にも $\mathrm{CA}$ 分子にも際立った熱因子の広がりは存在せず、秩序 の乱れは認められない。その他の原因として考えられる のは、分子の積層方向に沿っての音響型格子振動の変化 である。本錯体の結晶格子は単斜晶系で、低温相の空間 群は $P n$ 、高温相は $P 2_{1} / n$ である。分子の積層方向は $[1$, $-1,0]$ であるが、 NI 転移で $\mathrm{b}$ 軸は $5 \mathrm{pm} 、 \mathrm{c}$ 軸は $1.2 \mathrm{pm}$ 増加する ${ }^{88)}$ 。イオン性の低温相でペアリングしていた TTF と CA 分子が、中性の高温相ではより等間隔に近く

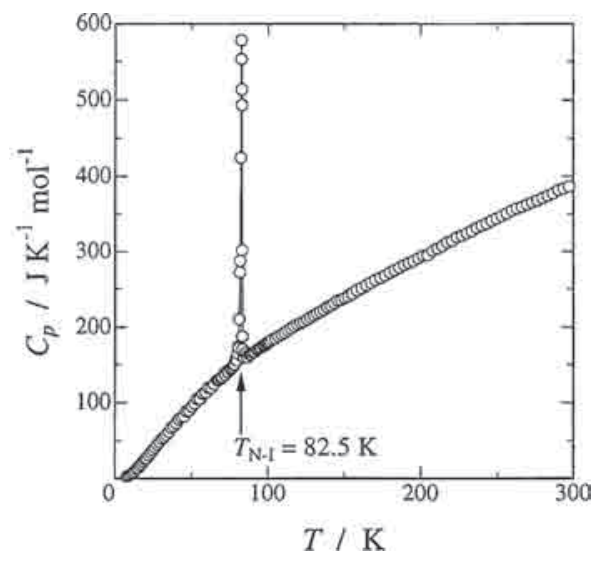

Fig. 35 Molar heat capacity of the charge transfer comples TTFCA. ${ }^{86)}$ 
配列するので、積層軸に沿っての音響型縦波をはじめ他 の格子振動がソフト化し、エントロピーに寄与するとい う可能性である。エントロピーには秩序・無秩序型のよ うな運動以外に、このような格子振動の状態密度の変化 も敏感に反映するのである。

\section{8. サーモクロミズム現象と相転移}

温度変化で物質の色が変わるサーモクロミズムは、有 機化合物 ${ }^{89)}$ や金属錯体 ${ }^{90,91)}$ でよくみられる。物質の色 は構造色を除けば、電子状態によって定まるので、サ ーモクロミズムには電子状態の変化が必ず伴っている。 金属錯体の場合は、金属と配位子からなる発色団の電 子エネルギーが、(i) 電子配置の変化、(ii) 配位構造の変 化、(iii) 配位数の変化、(iv) 配位子の分子運動などで摂 動を受ける。(i) の典型例はスピンクロスオーバーであ る。(ii)でよく知られた例は $\mathrm{Ni}^{2+}$ や $\mathrm{Cu}^{2+}$ の 4 配位シッフ 塩基からなる構造異性体である。平面 4 配位構造のとき は反磁性で緑色だが、四面体配位では常磁性で褐色とな る ${ }^{92)}$ 。筆者らは 2 種類のニッケル錯体の熱的性質と磁気 的性質の関係を詳しく研究し、反磁性の緑色結晶が熱力

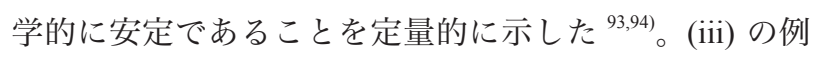
として、筆者らは $\left[\left(i-\mathrm{C}_{3} \mathrm{H}_{7} \cdot \mathrm{NH}_{3}\right)^{+} \mathrm{Cu}^{\mathrm{II}} \mathrm{Cl}_{3}\right]$ の熱測定を行な つた ${ }^{95)}$ 。低温結晶相は褐色で 5 配位錯体だが、高温相は 橙色で 6 配位となる。サーモクロミズムを伴う相転移は $330 \mathrm{~K}$ 近辺で起こるが、大きな過熱と過冷却現象を伴う のが特徴である。

(iv) の配位子の分子運動に基づくサーモクロミズムの 例を 2 つ紹介する。1つは $\left[\mathrm{M}(\text { dieten })_{2}\right] \mathrm{X}_{2}\left(\mathrm{M}: \mathrm{Cu}^{2+}, \mathrm{Ni}^{2+}\right.$ 、 dieten: $N, N$-diethylethylenediamine、 $\left.\mathrm{X}: \mathrm{BF}_{4}^{-}, \mathrm{ClO}_{4}^{-}\right)$である。 銅錯体は昇温により結晶の色が赤から青紫に、ニッケ ル錯体は橙黄から赤に変化する。Fig. 36 は $\left[\mathrm{Cu}(\text { dieten })_{2}\right]$ $\left(\mathrm{ClO}_{4}\right)_{2}$ のモル熱容量である $\left.{ }^{96}\right) 。 317.64 \mathrm{~K}$ にサーモクロ ミズムを伴う相転移の鋭いピークが見いだされた。眓中 の点線は相転移部分を分離するために算出した正常熱容 量であるが、低温相と高温相の正常熱容量が、相転移温 度で $\Delta C\left(T_{\mathrm{trs}}\right)=46 \mathrm{~J} \mathrm{~K}^{-1} \mathrm{~mol}^{-1}$ の段差を生じている。この ことから格子振動の状態密度に大きな変化が起きている ことがうかがえる。相転移に伴うエンタルピーとエン トロピー変化は、 $\Delta_{\mathrm{trs}} H=17.43 \mathrm{~kJ} \mathrm{~mol}^{-1} 、 \Delta_{\mathrm{tr} S} S=55.21 \mathrm{~J} \mathrm{~K}^{-1}$ $\mathrm{mol}^{-1}$ と、予想をはるかに超える大きな值であった。西 森ら ${ }^{96)}$ は、この大きなエンタルピー変化を、配位子の パッカリング運動と配位構造の歪みによるエネルギー 変化で解釈した。X 線構造解析 ${ }^{97,98)}$ により、銅原子と 配位子エチレンジアミンの骨格原子が形成する 5 員環 CuNCCN が、低温相では静止しているが、高温相では パッカリング (puckering) 運動をしていることが判明し た。その際、3 原子 $\mathrm{CuNN}$ からなる平面はあまり動か
ず、主としてエチレン基の炭素原子がパッカリングして いる。そうすると運動モードとしては、2つの炭素原子 が揃って CuNN 面の上下を往復運動するものと、2つの 炭素原子が常に CuNN 面の反対側に位置して往復運動 するものが考えられる。本錯体には 2 つ配位子がある ので、運動モードの自由度としては合計 4 つとなる計 算の詳細は省略するが、低温相で静止していた 5 員環が、 相転移温度で一斉に運動を始め、4つのモードが同一の 調和振動子で近似できるものと仮定すると、エンタルピ 一変化として $\Delta H=8.0 \mathrm{~kJ} \mathrm{~mol}^{-1}$ が推定できる。また正常 熱容量の跳びとして $\Delta C=33 \mathrm{~J} \mathrm{~K}^{-1} \mathrm{~mol}^{-1}$ が推定できたが、 この值は実測の跳び $\Delta C\left(T_{\mathrm{trs}}\right)=46 \mathrm{~J} \mathrm{~K}^{-1} \mathrm{~mol}^{-1}$ の大きな部 分を占めている。

さらに構造解析から、低温相で平面 4 配位だった $\left[\mathrm{CuN}_{4}\right]$ 発色団が、高温相では配位子のパッカリング運 動の影響を受けて、少し四面体的に歪むことがわかっ ている。平面 4 配位 $D_{4 h}$ から四面体配位 $T_{d}$ に変化する 際の d 軌道エネルギーを角重なり模型 ${ }^{99,100)}$ で決定した のが Fig. 37 である ${ }^{96)}$ 。横軸の $\theta$ は隣接する窒素原子と 銅原子のなす角度 $\angle \mathrm{NCuN}$ である。色の変化は $d_{y z}, d_{x z}$ $\rightarrow d_{x^{2}-y^{2}}$ 遷移に基づいており、図中の矢印 $\Delta E(\theta)$ に対応 する。可視スペクトルの吸収極大が低温相の $\Delta E\left(90^{\circ}\right)=$ $20,700 \mathrm{~cm}^{-1}$ から高温相の $\Delta E(\theta)=19,305 \mathrm{~cm}^{-1}$ に変化する 101,102) ことから、高温相での角度 $\theta$ を推定できる。 $\mathrm{Cu}^{2+}$ が 9 電子系であることを考慮して、Fig. 37 から両相の エネルギー差を見積もると $\Delta H(\mathrm{AOM})=8.4 \mathrm{~kJ} \mathrm{~mol}^{-1}$ とな つた。これは発色団 $\left[\mathrm{CuN}_{4}\right]$ の幾何構造の違いによる工 ネルギー差である。これにパッカリングに基づくエネル ギー $8.0 \mathrm{~kJ} \mathrm{~mol}^{-1}$ を加算すると、転移エンタルピーの予 想值は $\Delta H=16.4 \mathrm{~kJ} \mathrm{~mol}^{-1}$ となり、実測值 $\Delta_{\mathrm{trs}} H=17.43 \mathrm{~kJ}$ $\mathrm{mol}^{-1}$ とほぼ一致する。相転移でのエンタルピー変化を 定量的に解釈するのは意外に困難だが、これらはかなり

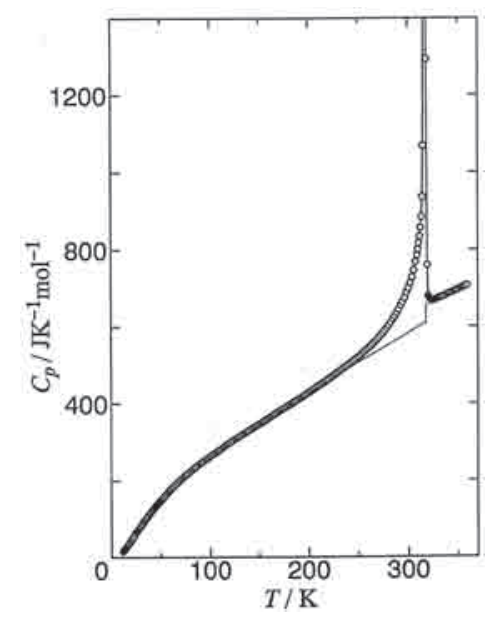

Fig. 36 Molar heat capacity of the thermochromic compound $\left[\mathrm{Cu}(\text { dieten })_{2}\right]\left(\mathrm{ClO}_{4}\right)_{2}$. Dotted curves shows the normal heat capacities of the LT- and HT-phases, resulting a heat capacity jump at the transition temperature. ${ }^{96)}$ 


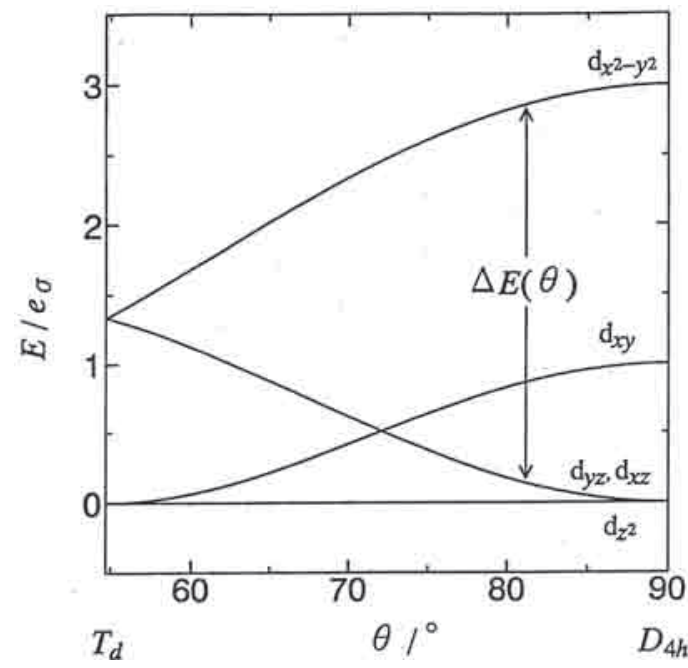

Fig. 37 Energy level diagram correlating tetrahedral and planar coordination geometries calculated on the basis of the angular overlap model.96)

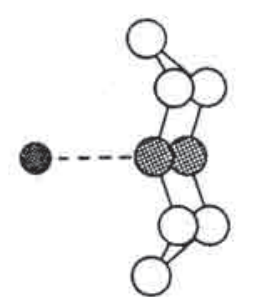

chair-chair

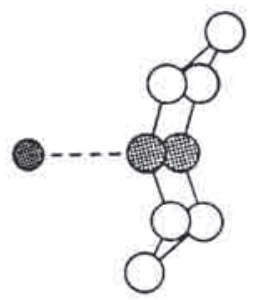

boat-chair

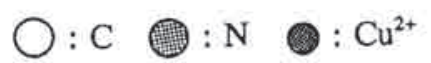

Fig. 38 Schematic drawing of four conformations of the eightmembered daco ring having almost equal energy. ${ }^{105)}$

\section{うまくいった例といえる。}

2 つ目の (iv) の例は、配位子の秩序・無秩序運動 によるサーモクロミズムである。 8 員環の配位子 daco (1,5-diazacyclooctane) 2 個を有する銅の平面 4 配位錯体 $\left[\mathrm{Cu}^{\mathrm{II}}(\mathrm{daco})_{2}\right]\left(\mathrm{NO}_{3}\right)_{2}$ は $360 \mathrm{~K}$ 近辺でオレンジ色から紫色 に変化する ${ }^{103)}$ 。サーモクロミズムの原因として、星野 $ら^{104)}$ はX 線構造解析に基づき、配位子と銅の相互作用 ではなく配位子と陰イオンの相互作用であろうと推論し た。

筆者ら ${ }^{105)}$ は熱容量測定を行い、359 K に相転移を見 いだした。相転移エントロピーは $\Delta_{\mathrm{trS}} S=(23.4 \pm 0.8) \mathrm{J} \mathrm{K}^{-1}$ $\mathrm{mol}^{-1}$ であった。このように大きなエントロピーの原因 として、一般的に予想されるのは配位子や陰イオンの秩 序・無秩序型の運動であるが、構造解析からは高温相 においても陰イオンは乱れていない。そこで注目した のが配位子 daco 分子のコンフォメーション変化である。 dacoのように単結合で結ばれた環状分子は、小さなエ ネルギーで大振幅の分子運動を行なうことができる。 daco 分子は Fig. 38 に模式的に示したように、N 原子と 3 つのメチレン基 $\left(-\mathrm{CH}_{2}-\mathrm{CH}_{2}-\mathrm{CH}_{2}-\right)$ が交互につながつ た 8 員環分子であり、2つの $\mathrm{N}$ 原子が $\mathrm{Cu}$ 原子に配位し ている。そのため daco 配位子にはエネルギーが似通つ た 4 つのコンフォメーションが考えられる ${ }^{105)}$ 。低温相 では分子間相互作用のためこれらの中のどれか 1 つのコ ンフォメーションが安定となるが、高温相では熱エネル ギーを得て分子運動が励起され、分子間相互作用が平均 化され、4つのコンフォメーションが等確率で出現して いると想像できる。もしこのメカニズムが妥当であれば、 本錯体にはdaco 配位子が 2 つ含まれているので、エン トロピーの増分は $2 R \ln 4\left(=23.05 \mathrm{~J} \mathrm{~K}^{-1} \mathrm{~mol}^{-1}\right)$ になるはず である。この值は実測の転移エントロピー $\Delta_{\mathrm{tr} S} S=(23.4 \pm$ 0.8) $\mathrm{J} \mathrm{K}^{-1} \mathrm{~mol}^{-1}$ とよく一致している。この事実から、大 きな転移エントロピーは配位子の秩序・無秩序運動に起 因していることが判明した。

この大振幅運動とサーモクロミズムの因果関係は、次 のように理解できる。室温での単結晶 X 線構造解析 ${ }^{104}$ では、発色団 $\mathrm{CuN}_{4}$ は正方形ではないが対称心のある 平面 4 配位構造をしている。しかし高温相では配位子 daco の大振幅運動のため、平面 4 配位が四面体的に少 し歪み、電子状態が摂動を受けるのでサーモクロミズム が起こると考えられる。Fig. 37 で説明した角重なり模 型が適用できる系である。

\section{9. おわりに}

熱力学には選択律や選択性が存在しないので、すべて の自由度が測定データに反映するのが特徴である。分子 磁性体ではスピン間相互作用の違いや磁気格子の次元性 が熱容量に敏感に反映し、あわせて秩序・無秩序型の分 子運動の励起もデータに取り込まれることを紹介した。 本稿では錯体に限定したが、熱力学は無機物・有機物、 低分子・高分子、結晶・非晶質、固体・液体、単成分系・ 多成分系、低温・高温などの区別なしに適用される。自 然界を支配しているのは熱力学の諸法則なので、エネル ギーやエントロピーの立場からも研究することが、自然 の仕組みや物質を正しく理解する上で不可欠である。

本稿ではエンタルピーよりもエントロピーに力点をお いてきた。端的に言えば、エントロピーは系の乱れ具合 や分子運動の激しさの指標であり、エンタルピーはその 
ような状態が実現するのに必要なエネルギーである。両 者の違いを、量子数が $1 / 2$ のスピンがアップとダウンの 2 方向を無秩序にとる常磁性から、配向が揃った強磁性 または反強磁性に変化する磁気相転移を例にして説明 しょう。1 次相転移を仮定すると、相転移は $\Delta G=\Delta H-$ $T \Delta S=0$ で起こるので、 $\Delta_{\mathrm{trs}} H=T_{\mathrm{trs}} \Delta_{\mathrm{trs}} S$ の関係がある。相 転移でのエントロピー変化は、スピンあたりの量子状態 が 2 通りなので、相転移温度 $T_{\mathrm{trs}}$ に無関係に $\Delta_{\mathrm{tr} S} S=R \ln 2$ $=5.76 \mathrm{~J} \mathrm{~K}^{-1} \mathrm{~mol}^{-1}$ となる。これにたいし、相転移エンタ ルピーは相転移温度 $T_{\mathrm{trs}}$ に比例するので、相転移が $1 \mathrm{~K}$ 、 $10 \mathrm{~K} 、 100 \mathrm{~K}$ で起こったとき $\Delta_{\mathrm{trs}} H$ はそれぞれ $5.76 \mathrm{~J} \mathrm{~mol}^{-}$ 1、57.6 J mol${ }^{-1} 、 576 \mathrm{~J} \mathrm{~mol}^{-1}$ となる。エンタルピーはエネ ルギーの一種なのでエントロピーより取り扱いが容易に 思えるが、どういう相互作用がどれくらい関与している かに依存するので、相転移エンタルピーの算定や解釈は 意外と困難なことが多い。標準生成エンタルピーとか化 学反応での熱の出入りを問題にするときには、エンタル ピーの值そのものを議論すればよいのだが、相転移のと きには、まず何が起こっているかということを追求する 必要がある。エントロピーの方は相互作用の大きさを考 えなくてもよいので、どういうことが起こっているかと いう事象そのものを研究するには、エントロピーという 熱力学量はたいへん便利なのである。

\section{謝辞}

はからずも錯体化学会貢献賞受賞の栄に浴することに なったが、これは熱測定の役割を錯体化学会賞等選考委 員会が高く評価してくださったお蔭と、敬意を表したい。 熱測定の重要性を教えていただいた恩師の関 集三先生、 ${ }^{57} \mathrm{Fe}$ メスバウアー分光によるスピンクロスオーバー研究 の場を与えていただいたギュートリッヒ (Philipp Gütlich) 教授に、あらためて感謝の意を表したい。本稿で紹介し た研究は、国の内外の多数の共同研究者、学生諸君の協 力を得て進められた。個々の氏名を列挙するのは割愛さ せていただくが、この場を借りて謝意を表したい。

\section{文献}

1) M. Sorai, Bull. Chem. Soc. Jpn., 74, 2223 (2001).

2) M. Sorai, J. Chem. Thermodyn., 34, 1207 (2002).

3) M. Sorai, M. Nakano, Y. Miyazaki, Chem. Rev., 106, 976 (2006); M. Sorai, Y. Nakazawa, M. Nakano, Y. Miyazaki, Chem. Rev., 113, PR41 (2013)

4) 徂徠道夫, 「相転移の分子熱力学」, 朝倉化学大系 10 , 朝倉 書店 (2007).

5) S. Murakawa, T. Wakamatsu, M. Nakano, M. Sorai, H. Suga, J. Chem. Thermodyn., 19, 1275 (1987).

6) M. Sorai, K. Kaji, Y. Kaneko, J. Chem. Thermodyn., 24, 167 (1992).
7) K. Kambe, J. Phys. Soc. Jpn., 5, 48 (1959).

8) J. Wucher, J. D. Wasscher, Physica, 20, 721 (1954).

9) B. N. Figgis, G. B. Robertson, Nature, 205, 694 (1965).

10) N. Uryû, S. A. Friedberg, Phys. Rev., 140, A1803 (1965).

11) M. Sorai, M. Tachiki, H. Suga, S. Seki, J. Phys. Soc. Jpn., 30, 750 (1971).

12) J. Ferguson, H. U. Güdel, Chem. Phys. Lett., 17, 547 (1972).

13) M. Morita, Y. Kato, Int. J. Quantum Chem., 18, 625 (1980).

14) L. Dubicki, J. Ferguson, B. Williamson, Inorg. Chem., 22, 3220 (1983).

15) K. J. Schenk, H. U. Güdel, Inorg. Chem., 21, 2253 (1982).

16) T. Yosida, M. Morita, M. Date, J. Phys. Soc. Jpn., 57, 1428 (1988).

17) M. Nakano, T. Wakamatsu, M. Sorai, H. Suga, J. Phys. Chem. Solids, 49, 987 (1988).

18) B. F. Hoskin, R. L. Martin, A. H. White, Nature, 211, 627 (1966); B. F. Hoskin, A. H. White, J. Chem. Soc. A, 1668 (1970).

19) H. H. Wickman, A. M. Trozzolo, H. J. Williams, G. W. Hull, F. R. Merritt, Phys. Rev., 155, 563 (1967).

20) R. L. Martin, A. H. White, Inorg. Chem., 6, 712 (1967).

21) N. Arai, M. Sorai, H. Suga, S. Seki, J. Phys. Chem. Solids, 38, 1341 (1977).

22) J. S. Miller, J. C. Calabrese, H. Rommelmann, S. R. Chittipeddi, J. H. Zhang, W. M. Reiff, A. J. Epstein, J. Am. Chem. Soc., 109, 769 (1987).

23) A. J. Epstein, S. Chittipeddi, A. Chakraborty, J. S. Miller, J. Appl. Phys., 63, 2952 (1988).

24) M. Nakano, M. Sorai, Chem. Phys. Lett., 169, 27 (1990).

25) A. Chakraborty, A. J. Epstein, W. N. Lawless, J. S. Miller, Phys. Rev. B, 40, 11422 (1989).

26) D. M. Duggan, D. N. Hendrickson, Inorg. Chem., 14, 955 (1975).

27) H. Tamaki, Z. J. Zhong, N. Matsumoto, S. Kida, M. Koikawa, N. Achiwa, Y. Hashhimoto, H. Ôkawa, J. Am. Chem. Soc., 114, 6974 (1992).

28) T. Hashiguchi, Y. Miyazaki, K. Asano, H. Tamaki, N. Matsumoto, H. Ôkawa and M. Sorai, Mol. Cryst. Liq. Cryst., 342, 185 (2000).

29) T. Hashiguchi, Y. Miyazaki, K. Asano, M. Nakano, M. Sorai, H. Tamaki, N. Matsumoto, H. Ôkawa, J. Chem. Phys., 119, 6856 (2003).

30) S. Decurtins, H. W. Schmalle, H. R. Oswald, A. Linden, J. Ensling, P. Gütlich, A. Hauser, Inorg. Chim. Acta, 216, 65 (1994).

31) S. Otsuka, A. Nakamura, T. Yoshida, Liebigs Ann. Chem., 719, 54 (1968).

32) H. Vahrenkamp, V. A. Uchtman, L. F. Dahl, J. Am. Chem. Soc., 90, 3272 (1968).

33) M. Sorai, A. Kosaki, H. Suga, S. Seki, T. Yoshida, S. Otsuka, Bull. Chem. Soc. Jpn., 44, 2364 (1971).

34) J. W. Edwards, G. L. Kington, R. Mason, Trans. Faraday Soc., 56, 660 (1960).

35) C. R. Pulliam, J. B. Thoden, A. M. Stacy, B. Spencer, M. H. Englert, L. F. Dahl, J. Am. Chem. Soc., 113, 7398 (1991).

36) P. D. Frisch, L. F. Dahl, J. Am. Chem. Soc., 94, 5082 (1972).

37) N. Kamijo, T. Watanabe, Acta Crystallogr., B35, 2537 (1979).

38) Y. Tanabe, S. Sugano, J. Phys. Soc. Jpn., 9, 753, 766 (1954).

39) E. König, K. Madeja, Inorg. Chem., 6, 48 (1967).

40) W. A. Baker, J., H. M. Bobonich, Inorg. Chem., 3, 1184 (1964).

41) M. Sorai, S. Seki, J. Phys. Soc. Jpn., 33, 575 (1972).

42) M. Sorai, S. Seki, J. Phys. Chem. Solids, 35, 555 (1974).

43) 上村 洸, 菅野 暁, 田辺行人, 「配位子場理論とその応用」, 裳華房 (1969). 
44) J. H. Takemoto, B. Hutchinson, Inorg. Chem., 12, 705 (1973).

45) A. Bousseksou, J. J. McGarvey, F. Varret, J. A. Real, J.-J. Tuchagues, A. C. Dennis, M. L. Boillot, Chem. Phys. Lett., 318, 409 (2000).

46) G. Brehm, M. Reiher, S. Schneider, J. Phys. Chem. A, 106, 12024 (2002).

47) B. Gallois, J.-A. Real, C. Hauw, J. Zarembowitch, Inorg. Chem., 29, 1152 (1990).

48) Spin Crossover in Transition Metal Compounds I, II, III (Top. Curr. Chem., Vol. 233, 234, 235), P. Gütlich, H. A. Goodwin (ed), Springer Verlag, Berlin/Heidelberg (2004).

49) P. Gütlich, A. Hauser, H. Spiering, Angew. Chem. Int. Ed., 33, 2024 (1994).

50) G. A. Renovitch, W. A. Baker, Jr., J. Am. Chem. Soc., 89, 6377 (1967).

51) M. Sorai, J. Ensling, K. M. Hasselbach, P. Gütlich, Chem. Phys., 20, 197 (1977).

52) M. Sorai, J. Ensling, P. Gütlich, Chem. Phys., 18, 199 (1976).

53) T. Nakamoto, A. Bhattacharjee, M. Sorai, Bull. Chem. Soc. Jpn., 77, 921 (2004).

54) K. Kaji, M. Sorai, Thermochim. Acta, 88, 185 (1985).

55) H. Köppen, E. W. Müller, C. P. Köhler, H. Spiering, E. Meissner, P. Gütlich, Chem. Phys. Lett., 91, 348 (1982).

56) M. Mikami, M. Konno, Y. Saito, Chem. Phys. Lett., 63, 566 (1979).

57) M. Mikami, M. Konno, Y. Saito, Acta Crystallogr. Sect. B, 36, 275 (1980).

58) T. Nakomoto, Z.-C. Tan, M. Sorai, Inorg. Chem., 40, 3805 (2001).

59) J. Frenkel, Kinetic Theory of Liquids, Oxford University Press, London (1947).

60) M. Sorai, Y. Yumoto, D. M. Halepoto, L. F. Larkworthy, J. Phys. Chem. Solids, 54, 421 (1993).

61) M. Sorai, Y. Maeda, H. Oshio, J. Phys. Chem. Solids, 51, 941 (1990).

62) P. E. Doan, B. R. McGarvey, Inorg. Chem., 29, 874 (1990).

63) S. M. Oh, D. N. Hendrickson, K. L. Hassett, R. E Davis, J. Am. Chem. Soc. 106, 7984 (1984); ibid. 107, 8009 (1985).

64) S. E. Woehler, R. J. Wittebort, S. M. Oh, T. Kambara, D. N. Hendrickson, D. Inniss, C. E. Strouse, J. Am. Chem. Soc., 109, 1063 (1987).

65) T. Kambara, D. N. Hendrickson, M. Sorai, S. M. Oh, J. Chem. Phys., 85, 2895 (1986).

66) M. Nakano, M. Sorai, J. B. Vincent, G. Christou, Ho G. Jang, D. N. Hendrickson, Inorg. Chem., 28, 4608 (1989).

67) S. M. Oh, T. Kambara, D. N. Hendrickson, M. Sorai, K. Kaji, S. E. Woehler, R. J. Wittebort, J. Am. Chem. Soc., 107, 5540 (1985).

68) M. Sorai, K. Kaji, D. N. Hendrickson, S. M. Oh, J. Am. Chem. Soc., 108, 702 (1986).

69) M. Sorai, D. N. Hendrickson, Pure Appl. Chem., 63, 1503 (1991).

70) H. Kitagawa, N. Onodera, J.-S. Ahn, T. Mitani, M. Kim, Y. Ozawa, K. Toriumi, K. Yasui, T. Manabe, M. Yamashita, Mol. Cryst. Liq. Cryst., 285, 311 (1996).

71) H. Kitagawa, N. Onodera, J.-S. Ahn, T. Mitani, K. Toriumi, M. Yamashita, Synth. Met., 86, 1931 (1997).

72) H. Kitagawa, N. Onodera, T. Sonoyama, M. Yamamoto, T. Fukawa, T. Mitani, M. Seto, Y. Maeda, J. Am. Chem. Soc., 121, 10068 (1999).

73) M. Kim, K. Takata, Y. Ozawa, K. Toriumi, 私信 .

74) Y. Miyazaki, Q. Wang, A. Sato, K. Saito, M. Yamamoto, H. Kitagawa, T. Mitani, M. Sorai, J. Phys. Chem. B, 106, 197 (2002).
75) N. Kojima, W. Aoki, M. Seto, Y. Kobayashi, Yu. Maeda, Synth. Met., 121, 1796 (2001).

76) N. Kojima, W. Aoki, M. Itoi, Y. Ono, M. Seto, Y. Kobayashi, Yu. Maeda, Solid State Commun., 120, 165 (2001).

77) T. Nakamoto, Y. Miyazaki, M. Itoi, Y. Ono, N. Kojima, M. Sorai, Angew. Chem. Intl. Ed., 40, 4716 (2001).

78) A. Bhattacharjee, Y. Miyazaki, M. Sorai, J. Phys. Soc. Jpn., 69, $479(2000)$.

79) A. Bhattacharjee, M. Sorai, J. Alloys Compd., 326, 251 (2001).

80) A. Bhattacharjee, Y. Miyazaki, M. Sorai, J. Magn. Magn. Mater, 280, 1 (2004).

81) R. D. Shannon, Acta Crystallogr. Sect. A, 32, 751 (1976).

82) M. Itoi, A. Taira, M. Enomoto, N. Matsushita, N. Kojima, Y. Kobayashi, K. Asai, K. Koyama, T. Nakano, Y. Uwatoko, J. Yamaura, Solid State Commun., 130, 415 (2004).

83) J. B. Torrance, A. Girlando, J. J. Mayerle, J. I. Crowley, V. Y. Lee, P. Batail, S. J. LaPlaca, Phys. Rev. Lett., 47, 1747 (1981).

84) C. S. Jacobsen, J. B. Torrance, J. Chem. Phys., 78, 112 (1983).

85) A. Girlando, F. Marzola, C. Pecile, J. B. Torrance, J. Chem. Phys., 79, 1075 (1983).

86) T. Kawamura, Y. Miyazaki, M. Sorai, Chem. Phys. Lett., 273, 435 (1997).

87) J. J. Mayerle, J. B. Torrance, J. I. Crowley, Acta Cryst., B35, 2988 (1979).

88) M. Le Cointe, M. H. Lemée-Cailleau, H. Cailleau, B. Toudic, L. Toupet, G. Heger, F. Moussa, P. Schweiss, K. H. Kraft, N. Karl, Phys. Rev. B, 51, 3374 (1995).

89) J. H. Day, Chem. Rev., 63, 65 (1963).

90) D. R. Bloomquist, R. D. Willett, Coord. Chem. Rev., 47, 125 (1982).

91) K. Sone, Y. Fukuda, Inorganic Thermochromism, Springer, Berlin (1987).

92) S. Yamada, A. Takeuchi, Coord. Chem. Rev., 43, 187 (1982).

93) N. Arai, M. Sorai, S. Seki, Bull. Chem. Soc. Jpn., 45, 2398 (1972).

94) Q. Wang, A. Takeuchi, Y. Yamamura, K. Saito, W. Mori, M. Sorai, J. Phys. Chem. B, 112, 11039 (2008).

95) A. Nishimori, M. Sorai, J. Phys. Chem. Solids, 60, 895 (1999).

96) A. Nishimori, E. A. Schmitt, D. N. Hendrickson, M. Sorai, $J$. Coord. Chem., 37, 327 (1996).

97) M. M.Andino, J. D. Curet, M. M. Muir, Acta Crystallogr. Ser. B, 32, 3185 (1976).

98) L. Grenthe, P. Paoletti, M. Sandström, S. Glikberg, Inorg. Chem., 18, 2687 (1979).

99) J. K. Burdett, Adv. Inorg. Chem. Radiochem., 21, 113 (1978).

100) A. B. P. Lever, Inorganic Electronic Spectroscopy (2nd ed), Elsevier, Amsterdam (1984).

101) A. B. P. Lever, E. Montovani, J. C. Donini, Inorg.Chem., 10, 2424 (1971).

102) J. R. Ferraro, L. J. Basile, L. R. Garcia-Ineguez, P. Paoletti, L. Fabbrizzi, Inorg. Chem., 15, 2342 (1976).

103) S. Yamaki, Y. Fukuda, K. Sone, Chem. Lett., 269 (1982).

104) N. Hoshino, Y. Fukuda, K. Sone, K. Tanaka, F. Marumo, Bull. Chem. Soc. Jpn., 62, 1822 (1989).

105) H. Hara, M. Sorai, J. Phys. Chem. Solids, 56, 223 (1995). 


\section{Profile}

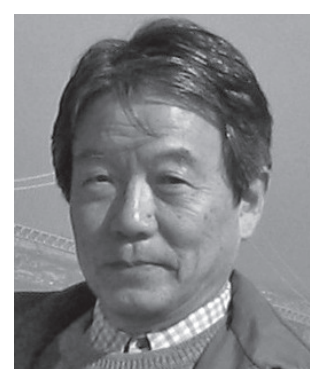

\section{徂徠 道夫}

大阪大学名誉教授 理学博士

[ 経歴] 1962 年大阪大学理学部卒業、1964 年大阪大学大学院理学研究科修士課程修了、 1964 年大阪大学理学部教務員、1966 年助手、1974 年西ドイツ国アレキサンダー・フォン・ フンボルト財団博士研究員（1 年 10 ケ月）、1981 年助教授、1987 年大阪大学理学部教授、 1993 年理学部附属ミクロ熱研究センター長、1999 年大阪大学大学院理学研究科教授、1999 年大学院理学研究科附属分子熱力学研究センター長、日本熱測定学会会長 (2 年間)、2001 年 ハフマン記念賞 (The Hugh M. Huffman Memorial Award) を受賞、2003 年大阪大学定年退官（名 誉教授)、2006 年 ポーランド科学アカデミー名誉教授

[専門] 分子熱力学、物理化学 